\title{
Chiropteran (Chiroptera; Mammalia) taxonomy in light of modern methods and approaches
}

\author{
Sergei V. Kruskop* \& llya V. Artyushin
}

\begin{abstract}
Bats are the second largest mammalian order with an almost worldwide distribution. Bat taxonomy remained almost unchanged for decades, and the diversity of the order was underestimated. The advent of molecular methods brought change to chiropteran taxonomy. The number of families increased from 17-18 to 21, and the relationships between them were revised, as were the composition of suborders and superfamilies. The number of recognized species and genera went up by almost a third. As a discipline, bat taxonomy has changed much methodologically and conceptually. After its long reign, comparative morphology has faded into the background. It has become clear that characters can diverge and converge in related species, masking true phylogenetic relationships. Not writing morphology off entirely, it does necessitate resorting to finer structures or multivariate data analysis. Karyology is of limited use in bat taxonomy, but methods such as FISH add to the understanding of relationships between suprageneric taxa. Mitochondrial DNA sequences are easy to obtain, and their analysis yields well-supported phylogenetic trees, but reticular processes and other factors may mask taxon boundaries. To resolve the uncertainty, nuclear markers are used, and their number and choice depends on taxon characteristics. Overall, building a consistent chiropteran system calls for an integration of all mentioned approaches.
\end{abstract}

How to cite this article: Kruskop S.V., Artyushin I.V. 2021. Chiropteran (Chiroptera; Mammalia) taxonomy in light of modern methods and approaches // Russian J. Theriol. Vol.20. No.2. P.111-128. doi: 10.15298/ rusjtheriol.20.2.01

KEY WORDS: Chiroptera, bats, molecular genetics, morphology, paleontology, karyology, phylogeny.

SergeyV. Kruskop [kruskop@zmmu.msu.ru], Zoological Museum, Moscow State University, Bolshaya Nikitskaya 2, Moscow 125009, Russia; Iliya V.Artyshin [sometyx@gmail.com], Department of the Vertebrate Zoology, Moscow State University, Leninskie Gory 1-12, Moscow 119234, Russia.

\section{Систематика рукокрылых (Chiroptera; Mammalia) в свете современных методов и подходов}

\author{
С.В. Крускоп ${ }^{*}$ И.В. Артюшин
}

РЕЗЮМЕ. Рукокрылые - второй крупнейший (после грызунов) отряд млекопитающих, имеющий почти всесветное распространение. Взгляды на их систематику десятилетиями оставались почти неизменными, и, как теперь понятно, разнообразие отряда на всех таксономических уровнях было в значительной степени недооценено. Однако с распространением молекулярных методов и постепенным совершенствованием самих этих методов представления о систематике рукокрылых стали значительно меняться. Оказались пересмотрены количество семейств (их число возросло с 17-18 до 21) и родственные связи между ними, состав подотрядов и надсемейств. Число признаваемых видов и родов за два десятилетия выросло почти на треть. За последние три десятилетия сформировались представления об эффективных методах и подходах при изучении систематики рукокрылых. Сравнительная морфология, доминировавшая ранее, отошла на второй план. Стало понятно, что на уровне родственных видов качественные и количественные признаки могут легко как дивергировать, так и конвергировать, маскируя истинные родственные связи. Это, однако, не списывает морфологию со счетов, а лишь требует обращения к более тонким структурам или к многомерному анализу данных. Кариология у рукокрылых — в среднем менее эффективный инструмент, однако такие методы как FISH дополняют представления о родственных связях надродовых таксонов. Получать последовательности митохондриальной ДНК сравнительно легко, а их анализ нередко дает хорошо поддержанные филогенетические деревья. Однако ряд факторов, таких как ретикулярные процессы, маскирует границы таксонов. Соответственно, широкое применение

\footnotetext{
* Corresponding author
} 
находят ядерные маркеры, выбор и количество которых зависит от особенностей анализируемого таксона. В целом же, для построения непротиворечивой системы необходима разумная интеграция перечисленных подходов.

КЛЮЧЕВЫЕ СЛОВА: Chiroptera, рукокрылые, молекулярная генетика, морфология, палеонтология, кариология, филогения.

\section{Introduction}

Bats are second largest Mammalian order, accounting for about $1 / 5$ of total taxonomic diversity of the class (Wilson \& Reeder, 2005; Wilson \& Mittermeier, 2019). There is a belief, as ingrained as it is wrong, that bats are poorly studied and that we know little of their taxonomy and paleontology. In reality, bats are very actively studied, and many discoveries have been made over recent decades, many of them intriguing and conducive to further research.

Chiropteran taxonomy remained remarkably stable for most of the 20th century, changing little from Tate's classic works (Tate, 1941a, b, c, 1942) to Koopman's checklists (Koopman, 1993, 1994). The number of recognized species changed insignificantly over the period, always staying near 900 (Koopman, 1984, 1993 , 1994). "A species is what a good taxonomist considers a species" was the motto of the era. It was the same for large taxa, adopted with slight variation from Dobson (1875) and Miller (1907). From thirties to nineties, only one new family, Craseonycteridae, was recognized following the discovery of the enigmatic Craseonycteris thonglongyai (Hill, 1974). Little change in chiropteran taxonomy meant few researchers took interest in it, producing, in turn, little change. Those few experts reigned the field uncontestedly, following their heart in their largely arbitrarily judgment.

Karyology fad, for all its impact on the taxonomy of other mammalian groups, in the case of bats had surprisingly little influence. One reason for that was inaccessibility of materials from the tropics, where the main diversity of the order is concentrated. The other reason was low variability of karyotypes in the groups of bats that were accessible to European and North American researchers. For instance, all Eptesicus species have the same number of chromosomes and chromosome arms $2 \mathrm{n} / \mathrm{FN}=50 / 48$ (Volleth \& Heller, 1994). In the second largest mammalian genus, Myotis, most species have karyotypes with 2 n/FN $=44 / 50-52$ (Volleth, 1987; Volleth \& Heller, 2012).

Things changed with the advent of molecular genetic techniques. Sampling tissue for DNA analysis is easier and more permissive than chromosomal preparations, facilitating material collection even in the tropics. The progress in methods themselves has allowed to analyze legacy material from old collections (Nachman, 2013; Almeida et al., 2014; Bailey et al., 2016; Castañeda-Rico et al., 2020). Bat capture techniques have improved as well. As a result, more extensive and varied material is now available for analysis than ever before. At the same time, the Genetic Species Concept (GSC) became key to alpha-level mammalian taxonomy (e.g., Bradley \& Baker, 2001; Baker \& Bradley, 2006). GSC was followed by the General Lineage Concept (GLC), where species are defined as metapopulation lineages identifiable by secondary recognition criteria (De Queiroz, 2007). Building on GSC is the idea of determining the rank of higher taxa by the time of their genetic isolation (see Avise \& Liu, 2011).

As a result, chiropteran taxonomy was revised at many levels, from suborders (Teeling, 2005; Hutcheon $\&$ Kirsch, 2006) to genera and species complexes (Ruedi \& Mayer, 2001; Appleton et al., 2004; Spitzenberger et al., 2006; Ruedi et al., 2013; Foley et al., 2017). The number of recognized species went up by $\sim 55 \%$ (Wilson \& Mittermeier, 2019). Here we review current bat taxonomy at different taxonomic levels and how it changed over the past two decades.

\section{Molecular genetic methods in bat taxonomy}

Since the late nineties, evidence from molecular genetics has changed chiropteran systematic at every level. In the late nineties and the noughties, infraorders were rearranged in the course of the grand molecular revision of high level mammalian taxonomy. At the same time, results from molecular barcoding projects led to changes in many families (discussed below) and genera, revealing a plethora of cryptic species in Emballonuridae (Goodman et al., 2012), Hipposideridae (Thabah et al., 2006; Vallo et al., 2008), Rhinolophidae (Sun et al., 2009), Phyllostomidae (Solari \& Baker, 2006; Porter et al., 2007), Miniopteridae (Miller-Butterworth, 2005), Vespertilionidae (Kawai et al., 2003; Jacobs et al., 2006; Spitzenberger et al., 2006; Mayer et al., 2007; Hulva et al., 2010).

Late 2000s saw a major shift in perspective on molecular systematics (Edwards, 2009). The notions of phylogeny and tree diverged in two distinct concepts each. Today, anyone involved in phylogenetic research is aware of the terms "gene tree" and "species tree" and the divide between them. The change in attitude came with the realization that molecular barcoding was not, in fact, the taxonomic silver bullet. Incomplete lineage sorting, speciation with gene flow retention, and hybridization are among the things that make gene trees and species trees incongruent (Elworth et al., 2019).

Barcoding can still be used, with due caution, for specimen identification. Even in convoluted taxa, most species can be reliably identified using mitochondrial cytochrome- $c$ oxidase subunit I gene (COI), which is 
the standard barcoding marker for mammals (Ivanova et al., 2012). If the study area likely has undiscovered taxonomic diversity, complex taxa can be still identified to the genus level (Caraballo et al., 2020).

Mitochondrial markers are also useful for preliminary biodiversity survey and discovery of taxonomical problems in insufficiently studied regions and groups (Giménez et al., 2019). For bats, COI in many cases does not provide sufficient resolution, hence cyt $b, \mathrm{ND} 1$ or rRNA genes are often additionally used (Çoraman et al., 2020).

The relative ease of sequencing of mitochondrial genes, unfortunately, provokes their use as the main, or even the only, argument for solving taxonomic issues instead of considering them together with other, for example, morphological data.

This approach is justified in some cases, when for example the status of undoubtedly related, but geographically separated taxa is considered (e.g., Benda et al., 2016; Dietz et al., 2016). In other cases, drawing conclusions using a single mitochondrial marker creates more confusion and problems than it solves. An example is the African "pipistrelles", which were divided into several questionable genera in recent works. And the boundaries between these genera vary depending on the number of analyzed taxa (Hutterer et al., 2019; Monadjem et al., 2021) and require further clarification.

The fact that each group has its own set of available markers creates problems for combining datasets, but things are getting better as the number of sequences in public databases grows. Hypervariable fragments of mtDNA, the D-loop/control region, have been successfully used for certain groups (Gager et al., 2016; Centeno-Cuadros et al., 2019). This marker, however, should also be used with caution, as it is prone to heteroplasmy at least in some genera (Petri et al., 1996), besides there are very limited taxonomical coverage of reference sequences.

As high-throughput sequencing technology advances, acquiring whole mitogenomes becomes cheaper and faster. At the time of writing, there are about 400 mitogenomes of bats in the NCBI database. Unfortunately, most of them are useless to resolving taxonomy (compare Hassanin et al., 2020; and Nesi et al., 2021). The main pitfall of mitochondrial phylogenies is not the lack of information to resolve deep short branches, but rather the phylogenetic incongruence at the short branches.

At the species level and beneath population samples of mitochondrial sequences can be used to characterize gene flow barriers (as deviation from isolation by distance model) and to reconstruct historical demography (Tu et al., 2021). These two kinds of data can become a meaningful taxonomic argument in context of certain species concepts, or at least help pinpoint contact zones or range discontinuities. Intraspecific population structure, demographic and behavioral traits, such as population size or sex-dependent dispersion, in mitochondrial trees sometimes produce branching patterns usually associated with species-level divergence (Dávalos \& Russell, 2014). The authors propose to approach the species status as a statistical hypothesis and validate it by comparing a series of evolutionary models, some of which assume species divergence and others do not. A recommendation is also given to formally test datasets for sufficiency for drawing conclusions.

Most current works on taxonomic and biodiversity issues use up to three mitochondrial and a few nuclear genes, commonly 2-10 of them (Foley et al., 2017; Demos et al., 2019; Garbino et al., 2020; Tu et al., 2021). This set of markers is generally adequate to identify species and construct correct phylogenies even in the presence of introgressive hybridization. In more complex cases it can show the group needs more study.

Introgressive hybridization frequently followed by a complete replacement of certain haplotype is common in bats. Initially discovered as discordance between morphological and mitochondrial traits it was found in the last decade in many genera of Vespertilionidae (e.g., Sztencel-Jabłonka et al., 2012; Morales et al., 2017; Centeno-Cuadros et al., 2019), Pteropodidae (Nesi et al., 2021), Rhinolophidae (Mao et al., 2019), Mormoopidae (Méndez-Rodríguez et al., 2021) and other families. It therefore makes sense to exercise caution when considering taxonomical revisions which are based solely on mitochondrial markers.

Genotyping population samples of appropriate size using a limited number of sites allows to directly trace hybridization and localize zones where it has occurred previously or is still happening (Méndez-Rodríguez et al., 2021). For bats, the most frequently used nuclear genes are ABHD11, BGN, PRKC1, STAT5A, ROGDI, THY (Igea et al., 2010; Foley et al., 2014), RAG1, RAG2, BRCA1 (Teeling et al., 2000), vWF, DMP1, and ApoB (Meridith et al., 2011). Unfortunately, different authors use different gene sets even for the same taxa. This can in part be overcomed by combining trees with non-matching leaf set (supertree methods; see Akanni et al., 2015), instead of combining character matrices. A concatenated matrix of multiple genes can be used in conjunction with methods which assume or directly implement coalescent and species tree models (*BEAST, ASTRAL, BPP, SVDquartets and others). Multi-locus sequencing projects are costly and time-consuming, but multiplex PCR and high-throughput sequencing alleviate this to some extent, especially when the number of genes that need to be considered reaches a few dozen.

Microsatellites are still worthwhile as a relatively cheap method for assessing genetic pool isolation and finding traces of hybridization (Centeno-Cuadros et al., 2019; Méndez-Rodríguez, 2021). Question remains, how to interpret allopatric forms that are distinguishable by microsatellites, but otherwise very close (Dool, 2020). Even if not considered as species such forms deserve close attention of conservation scientists (Andriollo et al., 2018). Phylogenetic reconstructions using microsatellite markers demand external estimates of evolutionary rates, which contribute substantially to divergence time errors (Ellegren, 2004).

For complex phylogenies even dozens of markers are sometimes not enough. Some of the reasons for 
that are short branches at deep divergences, reticulated evolution, and recent speciation. In such cases, highthroughput sequencing can be used instead, resulting in datasets that are orders of magnitude larger than a few dozen Sanger-sequenced amplicons could provide, at a comparable price. Low coverage whole genome sequences, however, while being useful in population genetics applications and work with archived samples, are typically too redundant and still too expensive for taxonomic purposes (O'Toole et al., 2021). To address this matter, a broad spectrum of methods is employed. Their main purpose is to limit the sequenced fraction of genome to several percent, while yielding same loci across all samples.

Baits (UCE, exome sequencing, and custom baits panels) are sometimes used to that end, although the method still remains too expensive for mass use. Despite this limitation, it was successfully applied to several groups (Mao \& Rossiter, 2020; Nesi et al., 2021). It is suitable for museum specimens, and needs little adaptation or none at all to apply to wide systematic groups, coping fine with up to $15 \%$ nucleotide mismatches between bait and target (Bragg et al., 2016), or up to 39\% with modified protocol (Li et al., 2013).

Restrictase-aided methods (RAD-seq: Elshire et al., 2011) are cheaper but more labor-intensive and sensitive to DNA quality Using a closely related species reference genome is highly recommended for proper selection of restrictases and read mapping.

RNA-seq is an alternative to exome sequencing. It is cheaper at preparation stage, while the sequencing itself is priced comparably. RNA-seq requires RNA, so it cannot be used on preserved specimens, unless formaldehyde was used as fixative, and even then with limitations. Euthanasia and internal organs tissue sampling or cell culture growing are required, which can be a problem when studying protected species. Only a few phylogenetic studies were thus published that used RNA-seq (Lei \& Dong, 2016; Hawkins et al., 2019).

The number of sites required for analysis varies depending on the phylogenetic analysis algorithm. Many algorithms require all specimens or most of them to be characterized by all sites (tags, SNP etc.). In such cases filtration can reduce the data volume by an order of magnitude (e.g., Morales \& Carstens, 2018). The resulting ratio varies depending on the number of samples, and gets worse when low-quality specimens are added. The effect of diminished input on algorithm performance should be carefully considered (Molloy \& Warnow, 2017). The computational cost of analysis grows together with the dataset size, often forcing the use of less complex evolutionary models and simpler algorithms. This can result in major artifacts in the reconstructions. Care should be taken to ensure the analyzed loci meet the assumptions of the models and algorithms used. It makes sense to group loci by parameters of molecular evolution (evolutionary rate, GC-content, gamma-distribution parameter) and then to assess the contribution of each group in the support for each phylogenetic hypothesis.
Extensive datasets can be misleading by producing high values of traditional "quality of reconstruction" metrics (bootstrap index and Bayesian posterior probability) even in the presence of alternative phylogenetic signal (Huang et al., 2020). A correct model of evolutionary process is of crucial importance when dealing with such data (Philippe et al., 2011). This can be demonstrated on the studies of New World mouse-eared bats. Apparently, several species hybridized more than once in their history. Application of different coalescent methods not taking into account possible hybridization resulted in a number of very different, but well-supported phylogenies. Moreover, even for the nodes that were reconstructed correctly, divergence times will be estimated with significant systematic error if an algorithm is used that cannot handle correctly the gene flow retention after speciation (Leaché et al., 2014; Morales et al., 2017).

Papers, however, still appear where data is not checked for traces of reticulated evolution. For example, in Loureiro et al. (2020), the authors, revising the genus Molossus, consider monophyletic and very lowdivergence groups which correspond to morphologically distinguishable entities sufficient evidence to make taxonomical decisions

It is indeed complicated question how to treat forms, for which the gene flow retention or hybridization was shown, even if there is enough data to quantitatively describe this process. Taxonomical conclusions can be arbitrary and ultimately depend on the choice of species concept. For higher taxonomical levels, monophyly and divergence time are the main considered criteria (Avise \& Liu, 2011). Many nodes above the generic level that lack resolution can be easily resolved just by increasing the number of genes in the dataset. However, divergence events occurring in rapid succession can produce patterns close to true polytomy. In that case, the number of loci that corroborate alternative phylogenies can be nearly equal, and uttermost care should be taken to apply correct data filtration, that is excluding paralogs, genes with deviant evolutionary parameters, genes under positive selection etc.

\section{Role of morphology}

Since the very inception of zoology, morphological structures have been a precious source of information, which should not be discarded even with the advent of new methods. Until very recently, bat taxonomy studies at all levels based itself primarily on morphological data. First works trying to adapt molecular genetics to the needs of bat taxonomy date back to the late nineties. In the early $2000 \mathrm{~s}$, the approach gained traction - and shook the old system. Even after that, however, new studies based on morphological data kept coming out, with some of them pertaining to low-level taxonomy, (e.g., Csorba et al., 2007; Görföl et al., 2013; Reeder et al., 2013). Moreover, an important role in understanding the evolution of vertebrate taxonomy is played by 
paleontology, inevitably relying on morphological criteria (Wiens et al., 2010). Calibration of divergence times is particularly dependent on paleontological evidence (see, e.g., Wiens, 2009; Ksepka et al., 2015; Warnock et al., 2017).

On the other hand, morphological structures are prone to a large degree of individual, age-dependent, sexual, and geographic variability, as well as to homoplasy (Freeman, 2000; Evin et al., 2008; etc.). In alpha-level taxonomy, unless the sampling across the putative species range is sufficient to assess the variability, it is easy to misinterpret ecomorphs, remote but reproductively non-isolated populations, or just animals from different samples as a species. Conversely, when dealing with geographically distant populations representing ecological vicariates, it is difficult to critically assess their taxonomic relationships solely by morphological similarity. The long-standing notion of extremely wide transcontinental ranges of some bats is an example of this. The species Myotis daubentonii and Plecotus auritus had forms from eastern parts of their transpalaearctic ranges moved out into distinct species $M$. petax and P. ognevi (Matveev et al., 2005; Spitzenberger et al., 2006). The range of Miniopterus schreibersi, formerly spanning three continents, is now divided into a number of species, some of them not even related to each other (Appleton et al., 2004; Tian et al., 2004; Bilgin et al., 2012; Šrámek et al., 2013).

The situation is worse, in a sense, in the high-rank taxa. On the one hand, almost every family-rank taxon has its own morphological diagnosis matching its member taxa. Perhaps only the wing-gland bats Cistugidae represent the exception. The morphological distinction between Cistugidae and the related Vespertilionidae is obscure, and it is no more pronounced than the differences between suprageneric groups within Vespertilionidae itself (Lack et al., 2010).

On the other hand, syndromes of morphological traits, no matter how obvious they are, tend to say little about phylogenetic relationships, and even can mislead when they do. Pteropodidae, a family of Old World fruit bats, is a most striking example. Owing to their unique morphology, for more than a century they have been treated as special suborder Megachiroptera (Koopman, 1994; McKenna \& Bell, 1997). Molecular genetic and karyological evidence, however, places Pteropodidae close to the superfamily Rhinolophoidea (Teeling et al., 2002, 2005; Eick et al., 2005; Hutcheon \& Kirsch, 2006; Ao et al., 2007; Volleth et al., 2011), which today is usually no longer contested. Worthy of note is also the placing of all nectarivorous fruit bats into subfamily Macroglossinae, and of all nectarivorous leaf-nosed bats into subfamilies Phyllonycterinae and Glossophaginae (e.g., Koopman, 1994; McKenna \& Bell, 1997). It has been shown recently that adaptations to feeding on pollen and nectar had evolved several times in both families, giving rise to convergent syndromes of traits (Almeida et al., 2011, 2020; Baker et al., 2016; Camacho et al., 2019). "Serotines" and "pipistrelles" used to be formerly recognized as supra-genus groups, based on their formal dental features (e.g., Koopman, 1994), but other approaches showed this completely untenable (Volleth \& Heller, 1994; Kearney et al., 2002; Hoofer \& Van den Bussche, 2003; Roehrs et al., 2010, 2011).

Given all this, morphological evidence in modern bat taxonomy has come to play a secondary role, especially at the alpha level. Morphological characters are selected to describe the taxa already identified using molecular methods. Still, morphology remains an important source of information on many issues, including the rank of taxa (Springer et al., 2008; Cirranello et al., 2016; Rossini et al., 2019), which is one of the keys to the integrative approach in taxonomy (Padial et al., 2010; also see Davalos et al., 2014).

As with other mammals, in bats the most important, or indeed the most popular sets of discriminating characters are associated with the skull and dental structures. Bats do not have such noticeable differences in the shape of chewing surface as do the rodents. However, the totality of all teeth in a row usually creates a syndrome of traits specific to a particular taxon. This fact is well known to paleontologists and heavily used by them (Horáček et al., 2006; Gunnell et al., 2008; Rosina \& Rummel, 2012; Sigé et al., 2014; etc.). Neontologists, with more diverse and complete material at their disposal, usually limit themselves to general characterization of teeth structure, only occasionally showing interest in the particulars of dental morphology.

Morphological features such as teeth shape, however, should be interpreted with certain caution. For example, in the most extensive bat family, Vespertilionidae, there are two prevalent types of talonid structure of the lower molars, myotodontia and nyctalodontia (Menu \& Sigé, 1971; Horacek \& Hanak, 1986; Menu, 1987; Martie, 2014). Myotodontia is believed to be ancestral in Vespertilionidae, which is supported by the description of a myotodont bat, Premonycteris (Hand et al., 2016) from a late early Eocene. Menu (1987) assigned taxonomic significance to the distinction between myotodontia and nyctalodontia, and in most known cases it serves well as a marker for taxon boundaries. It is particularly helpful in paleontology, since the lower molars preserve well. However, a number of cases are known when members of closely related taxa possess different types of molars. For instance, all but few species in the extensive genus Myotis have molars of the myotodont type. Certain species in the generally morphologically compact complex "siligorensis", however, are an exception (Borisenko et al., 2008; Tiunov et al., 2011; Ruedi et al., 2013).

It is appropriate to say here few words about the paleontology of bats. Fossil evidence of bats is abundant, covering all continents and time periods in which chiropterans have ever lived, though gaps do remain (Gunnell \& Simmons, 2005; Eiting \& Gunnell, 2009). However, complete bone remnants allowing for comparison of multiple characters are rare. Most chiropteran fossil records are jaw fragments and isolated teeth, which limits the already scarce possibilities to construct phylogeny (see Smith et al., 2007; Rosina \& Rummel, 2012; Sigé et al., 2014; etc.). Still, the 
paleontological history of many modern bat genera and most modern bat families is fairly well described.

From a neontologist's perspective, paleontological approach meets two common problems. With fossils from completely extinct taxa, paleontologists must somehow deal with their classification and phylogenetic placement. But whenever the fossils in question have morphological features that give clues to place them with extant taxa, it would often be done even when contradicted by biogeographic reasons and molecular dating. To mention a few examples, some European longeared bat fossils were assigned to an endemic American genus Corynorhinus (e.g., Ziegler, 2003; but see Arita et al., 2014; Rosina et al., 2019); the description of Myotis species from the Early Oligocene of Belgium (Gunnell et al., 2017) and the assignment of the Oligocene genus Quinetia to the Plecotini tribe (Czaplewski et al., 2019) followed the same pattern. In two latter cases the fossil records are almost two times older than the molecular dating for basal divergence of their alleged taxa (see Teeling et al., 2005; Lack et al., 2010).

Integrating morphological evidence, including that from fossil records, into molecular phylogenetic reconstructions makes sense at least for taxa with extant species. In a study on American leaf-nosed bats Phyllostomidae, fossil evidence from Miocene genera Notonycteris and Palynephyllum is integrated into the molecular based reconstruction by isolating conflicting phylogenetic signals in analysis of non-independent morphological structures. As a result, a scenario for morphological evolution of Phyllostomidae is proposed (Davalos et al., 2014).

An interesting morphological study used computed microtomography to compare of the structure of the shoulder joint and inner ear of Tachypteron franzeni and modern Taphozoinae, showing the same level of adaptation to open-space aerial hawking in the modern and Eocene species. It had no direct relation to taxonomy, but it is important for understanding the time of formation of morphologically "modern" bats (Habersetzer et al., 2012).

Geometric morphometrics allows to formally describe and compare the shape of objects (Marcus et al., 2000; Zelditch et al., 2012). At the level of large taxa geometric morphometrics methods have been successfully applied to the New World leaf-nosed bats Phyllostomidae (Camacho et al., 2019; Rossoni et al., 2019; Hedrick et al., 2020). The latter work also examines how the shape of skull changes in leaf-nosed bats compared to closely related families. An earlier study focuses on the range of disparity within and between the three bat families Phyllostomidae, Molossidae, and Vespertilionidae (Hedrick \& Dumont, 2018). These and many other bat-related morphological studies have more to do with mechanisms and directions of evolution than with taxonomic research as such, making use of existing phylogenetic schemes derived earlier from molecular evidence. Methodologically, however, they may clue in new phylogenetic research by demonstrating the possibility of identifying and describing the trajectories of morphological evolution within known taxa.
More specific taxonomic papers use geometric morphometrics as one of the arguments for identifying a new taxon (Jarrín-V \& Kunz, 2011; Tu et al., 2015) or for finding boundaries between known species (Evin et al., 2008; Sztencel-Jablonka et al., 2009; Huang et al., 2014). The number of bat-related studies of this kind is small. Noteworthy is the work of Schmieder et al. (2015), comparing the reliability of geometric and traditional morphometrics, using European horseshoe bats Rhinolophus as an example.

In another study, 2D geometric morphometrics was used to explore the phylogenetic relationships between fossil and modern Rhinolophoidea (Wilson et al., 2016). Similarly to Davalos et al. (2014), fossil taxa were integrated into modern phylogenetic schemes (Murray et al., 2012; Foley et al., 2015). For the first time the fossil forms of Rhinonycteridae and Hipposideridae were reliably separated, clearly demonstrating the viability of the approach.

A recent study gives an example of morphology helping resolve doubts that molecular research creates. Since the early days of molecular-based research in bat phylogeny, question remained: in light of the relationship between fruit bats and rhinolophoids, did echolocation in the two bat suborders develop independently, or did they inherit it from a common ancestor, and then Pteropodidae lost it (Springer et al., 2001; Jones \& Teeling, 2006; Teeling, 2009)? An embryological study showed that in non-echolocating fruit bats the inner ear morphology is similar to that of non-bat placental mammals not only in adults, but also during embryonic development. In echolocating bats from both suborders, though, the development of the inner ear differs noticeably both from non-echolocating mammals and from each other. The balance thus shifts in favor of the independent origin of echolocation in two suborders (Nojiri et al., 2021).

\section{Role of chromosome studies in bat taxonomy}

Compared to molecular genetics and morphology, chiropteran taxonomy owes relatively little to karyology. As already mentioned, the "karyological boom" in mammalian taxonomy did not significantly affect bat taxonomy. At that time most studies were conducted on the accessible boreal species, mainly in the family Vespertilionidae, known for conservatism in chromosome morphology and numbers (e.g., Heller \& Volleth, 1984; Volleth, 1987). Bats in general, compared to other mammals, are also conservative in that respect (Sotero-Caio et al., 2017). As a result, until late nineties, karyological studies of bats were mostly descriptive and did not result in mass recognition of new taxa, as was the case with rodents and insectivores (e.g., Warner et al., 1974; Zima, 1976; Bickham et al., 1986; Hood et al., 1988; Zima et al., 1992; etc.).

Karyological evidence, however, did provide clues that helped correct the system, as it did for the placement of the genus Barbastella within the tribe Plecotini 
(Uchida \& Ando, 1972; Fedyk \& Ruprecht, 1983; Volleth, 1985); the assignment of species status to named taxa such as Macrotus californicus (Nelson-Rees et al., 1968) and Nyctalus furvus (Volleth, 1992); the removal of forms societatis and circumdatus from the genus Pipistrellus (Heller \& Volleth, 1984), etc.

Phyllostomidae have relatively high chromosomal variability among Chiroptera, with the largest number of chromosomal rearrangements and the greatest variety of diploid numbers within the order (Baker, 1973, 1979; Baker \& Bickham, 1980). The progress in Phyllostomidae taxonomy that could have been made by exploiting these properties, however, was made using molecular genetic evidence instead.

Fluorescence in-situ hybridization (FISH) technique has become a valuable tool, allowing to establish chromosome region homology even between unrelated species - an important insight into the evolution of karyotype (Wienberg, 1995; Graphodatsky et al., 2012). It was apparently first applied to bats by Volleth et al. (1999) to study the karyotype of Glossophaga soricina. A later study used homologies established by ZOO-FISH to identify synapomorphies, supporting the monophyly of the order Chiroptera, and also consistent with the hypothesis of the close relationship between Pteropodidae and Rhinolophoidea (Volleth et al., 2002, 2011).

Modern methods of chromosome painting and mapping have allowed to describe the karyotypes of diverse chiropteran species from all modern bat families, except Craseonycteridae. A detailed review of current knowledge in bat karyology was given by Sotero-Caio et al. (2017). The growing knowledge of bat karyotype evolution highlights many issues important to bat taxonomy, from intraspecific variability (e.g., Volleth et al., 2013; Gorobeiko et al., 2020; etc.) to composition and boundaries of suprageneric taxa. For example, karyological data allowed to question the existence of the tribe Nycticeiini in its traditional understanding (Volleth et al., 2006), in full agreement with the results of molecular genetic studies (e.g., Hoofer \& Van Den Busche, 2003; Roehrs et al., 2010). Study of the karyotypes of horseshoe bats (Rhinolophus) revealed cryptic taxonomic diversity in the species group "trifoliatus". As a result, species status was acknowledged for two taxa and a new species was described, $R$. luctoides (Volleth et al., 2015, 2017). Karyological data supported the clade Nullicauda within the family Phyllostomidae and did not support the merging of genera Carollia and Rhinophylla into one taxon (Gomes et al., 2018). Another studies, in Phyllostomidae, identified cryptic diversity in the genus Rhinophylla (Gomes et al., 2010) and clarified phylogenetic relationships in the subfamilies Micronycterinae (Benathar et al., 2019) and Vampyressinae (Gomes et al., 2016). The latter work revealed translocations between sex chromosomes and autosomes, unique among mammals, explaining the emergence of sex tri- and tetravalents. Although important for understanding the evolution of bat karyotypes, at this stage it does not introduce any novelty into phylogenies.
Many studies use karyological evidence as an element of integrated approach, in which case it becomes an extra argument to support a taxonomic hypothesis. Examples include the confirmation of generic rank of Neoromicia (Kearney et al., 2002), the description of cryptic diversity in Carollia castanea species complex (Solari et al., 2006), the description of the genus Hsunycteris and the tribe Hsunycterini (Parlos et al., 2014), and the study of phylogenetic relationships and cryptic diversity in the genus Kerivoula (Khan et al., 2010).

In a series of studies of the Emballonuridae family (Volleth et al., 2019a, b), cytogenetic evidence, in good agreement with the results from previous molecular genetic research, confirmed the relationship between Emballonuridae and Nycteridae, as well as a very ancient, divergence of Taphozoinae, possibly dating back to early Eocene, confirming Taphozoinae as an independent family.

\section{Recent changes in supra-generic taxonomy}

\section{Traditional views}

So what exactly changed in the taxonomy of bats over the past two decades, besides the rise in known species diversity? As Solari et al. (2019) point out, the construction of a stable and consistent bat taxonomy based on reliably reconstructed phylogenetic relationships is still a work in progress. However, as we demonstrate above, a lot has been done since the coming of molecular genetic methods and the integrative approach to makes use of them. Below, we briefly review the problems of supra-generic bat taxonomy seem to be solved or ready to be solved, as well as those that still await research.

As mentioned above, chiropteran system in premolecular era was mostly proposed by authors from the late $19^{\text {th }}$ to early $20^{\text {th }}$ century. It changed slightly by the end of the $20^{\text {th }}$ century, acquiring apparent completeness in the works by Koopman $(1984,1994)$ and Simmons $(1995,1998,2005)$. The system comprised unranked taxon Eochiroptera where Eocene fossil families were lumped together; suborder Megachiroptera with the single family Pteropodidae; and suborder Microchiroptera comprising all other extant families grouped in two infraorders. Infraorder Yinochiroptera included families Rhinolophidae, Hipposideridae (sometimes within Rhinolophidae), Megadermatidae, Craseonycteridae, Nycteridae, Rhinopomatidae, and Emballonuridae). Infraorder Yangochiroptera comprised families Noctilionidae, Mormoopidae, Phyllostomidae, Natalidae, Molossidae, Vespertilionidae, Tyropteridae, Furipteridae, Myzopodidae, and Mystacinidae.

This taxonomic scheme with minor variations was generally agreed upon and reproduced in numerous checklists and zoology texts. So what changed since then?

\section{Recent changes}

First of all, the composition of the suborders was revised. It was suggested (Teeling et al., 2000, 
2002; Springer et al., 2001), and then convincingly shown (Volleth et al., 2002, 2011; Hutcheon \& Kirsch, 2004, 2006; Teeling et al., 2005; Lei \& Dong, 2016) that Microchiroptera are paraphyletic; that the superfamilies Pteropodoidea (with a single family) and Rhinolophoidea are in sister positions to each other and together in sister position to all other extant taxa in the order. It was thus proposed to divide the order into suborders Yinpterochiroptera and Yangochiroptera, which Hutcheon \& Kirsch (2006) proposed to call Pteropodiformes and Vespertilioniformes. Among other things, this has raised the question of the origin of echolocation in bats. Since fruit bats, with their archaic structure of the inner ear, were no longer the basal branch in this system, is the absence of echolocation secondary in them, or was it acquired independently in both suborders (Eick et al., 2005; Teeling, 2009)? As already mentioned, the brilliant work of Nojiri et al. (2021) showed the second scenario was more likely.

This, in turn, raises the question of the relationship between families placed with Eochiroptera (e.g., sensu Sigé, 1991). Some of them (e.g. Tanzanycteridae) had already been suggested as putative archaic Rhinolophoidea (Gunnell et al. 2005; Hulva et al., 2007). The cladistic constructions of Simmons and Geisler (1998) suggested that Pteropodidae were in many respects more archaic, and thus more basal than all known fossil families, with possible exception for Icaronycteridae, as well as Onychonycteridae, latter still not known at the time (Simmons et al., 2008). According to current views, it automatically puts each of these extinct families into an extant suborder. The auditory anatomy paper mentioned earlier (Nojiri et al., 2021) undermines the counter-argument about primitivity of the inner ear structure in Onychonycteridae and Icaronycteridae. Current dating of the origin of bat superfamily taxa (Teeling, 2009; Teeling et al., 2016; Amador et al., 2018), partly supported by the recent discoveries of very early yet morphologically advanced bats (Storch et al., 2002; Hand et al., 2016), implies that that the divergence of modern bat suborders dates back to about the same period as the earliest bat fossil findings, or even earlier. This line of reasoning lends extra support to the placement of Eocene bat families with modern suborders.

According to recent evidence, Emballonuridae, some of the most morphologically archaic living bats, do not belong to Yinpterochiroptera, but rather to Yangochiroptera along with Nycteridae, placing the two families as sister groups (Van Den Busche \& Hoofer, 2004; Eick et al., 2005; Teeling et al., 2005). This scheme was initially proposed based on molecular findings and later supported by cytogenetic evidence (Volleth et al., 2019b). Conversely, Rhinopomatidae and Craseonycteridae are undoubtedly placed with Rhinolophoidea and are thus in no close relation to Emballonuridae (Hulva \& Horáček, 2002; Teeling et al., 2005; Hulva et al., 2007; Foley et al., 2015; Amador et al., 2018).

Natalidae and Molossidae are almost definitely related to Vespertilionidae and belong to the same superfamily (Hoofer et al., 2003). There is also not much doubt that Tyropteridae, Furipteridae, and Mystacinidae are related to other Noctilionoidea (Van Den Busche \& Hoofer, 2000, 2001; Hoofer et al., 2003; Agnarsson et al., 2011). In this list, the family Mystacinidae stands out as the only undoubted non-American member of the superfamily Noctilionoidea, indicating preOligocene divergence of the latter (Teeling et al., 2003). Madagascar sucker-footed bats Myzopodidae thus remain the only family o uncertain position. Various studies place Myzopodidae as part of basal radiation of either Vespertilionoidea (Van Den Busche \& Hoofer, 2004; Eick et al., 2005), Noctilionoidea (Teeling et al., 2005; Agnarsson et al., 2011), or even Yangochiroptera in general (Hoofer \& Van Den Busche, 2003), with invariably low support. Given the undoubted antiquity of Myzopodidae (Gunnell et al., 2014), the solution, for some reason never explicitly proposed before, might be to recognize them as a superfamily of their own.

The traditionally accepted set of families has been supplemented in the two recent decades by an extra three. Bent-wing bats Miniopteridae have long been considered a part of Vespertilionidae (see Koopman, 1994). Their independent status was substantiated by morphological evidence (Mein \& Tupinier, 1977) and, decades later, confirmed by molecular genetics. Among other things, it indicates pre-Oligocene divergence of Miniopteridae from other Vespertilionoidea (Miller-Butterworth et al., 2007; Lack et al., 2010). The placement of the genus Cistugo as a separate family was also based primarily on its ancient divergence, predating the divergence of modern groups within Vespertilionidae (Lack et al., 2010).

For all the morphological similarities between Rhinolophidae and Hipposideridae, especially striking in their early fossils (Ravel et al., 2016), their undoubted divergence in the Eocene (Ravel et al., 2014) rules out uniting them under one family. Additionally, phylogenetic analysis revealed a third lineage, almost as ancient, subsequently recognized as the family Rhinonycteridae (Foley et al., 2015).

Molecular (Ruedi et al., 2012), cytogenetic (Volleth et al., 2019a), and paleontological evidence (Storch et al., 2002; Habersetzer et al., 2012) indicates that Emballonurinae and Taphozoinae, the two subfamilies recognized within Emballonuridae, diverged no later than beginning of Middle Eocene. By analogy with other taxa in the order, this warrants assigning family rank to both subfamilies, which we reflected in the scheme below.

\section{The structure of large families}

At the turn of the 21st century, phylogenetic studies of the family Pteropodidae, including early molecular genetic efforts, revealed multiple contradictions within the existing system. Examples include paraphyly of nectarivorous genera, uncertain position of the genus Eidolon, paraphyly of the genus Rousettus in its traditional sense etc. (Kirsch et al., 1995; Hollar \& Springer, 1997; Alvarez et al., 1999; Juste et al., 1999; Romagnoli \& Springer, 2000). Molecular phylogenetic studies with representative taxonomic sampling formed 
a fairly consistent system of Pteropodidae (Almeida et al., 2011, 2016, 2020). These works confirmed a number of assumptions and made certain adjustments to them. They supported the subfamily status of Cynopterinae; showed the relation of Boneia, Dobsonia, and Aproletes to Harpyonycterinae (and not Rousettinae); the endemic African clade previously identified as subfamily Epomophorinae (Bergmans et al., 1997) was included in Rousettinae, which in turn was split into seven tribes. The genus Eidolon and the peculiar genus Notopteris, endemic to Fiji, Vanuatu, and New Caledonia, received the status of distinct monotypic subfamilies (Eidoloninae and Notopterinae, respectively).

The modern system of the family Phyllostomidae was developed by a number of authors based on molecular data and integrative approach (Baker et al., 2003, 2016; Davalos et al., 2014; Cirranello et al., 2016; Hedrick et al., 2019; Rossoni et al., 2019). In particular, the paraphyletic nature of Phyllostominae in its traditional understanding was shown (Baker et al., 2003; Hoffman et al., 2008). As a result, the genus Macrotus was recognized as a distinct and most basal subfamily (Baker et al., 2003), whereas Micronycterinae, Glyphonycterinae, and Lonchorhininae were designated as separate subfamilies (Cirranello et al., 2016). As mentioned earlier, it was also demonstrated that the transition to nectar diet had independently occurred on multiple occasions; producing nectarivorous leaf-nosed bats in different subfamilies Glossophaginae and Lonchophyllinae, both of which include not nectarfeeders as well (Baker et al., 2016; Rossoni et al., 2019).

The structure of another large family Vespertilionidae went through less revision. Tribe composition in the nominotypical subfamily received more attention, yet remains insufficiently established (Hoofer \& Van den Bussche, 2003; Roehrs et al., 2010, 2011). Decisive adoption of nomenclature for the tribes Vespertilionini and Pipistrellini is hindered, by the uncertain placement of the genus Vespertilio (close to the rest of Vespertilionini according to, e.g., Koubínová et al. (2013) and to Pipistrellini according to Roehrs et al. (2010), and also by the lack of formal description of "Hypsugine" group. The unity of the tribe Nycticeiini raises doubts (Hassanin et al., 2017; Amador et al., 2018). The boundaries and composition of the tribe Plecotini are not clear. In its traditional sense, it has weak support in all reconstructions (Hoofer \& Van den Bussche, 2001, 2003; Roehrs et al., 2010), with the position of the genera Otonycteris, Idionycteris, and Euderma especially controversial (Amador et al., 2018). High rate of substitutions in the family and the rapid diversification of its main clades in the Miocene (Lack \& Van Den Bussche, 2010) obstruct solution of these problems. As regards the composition and rank of subfamilies, molecular genetic evidence supports some of the earlier proposals. The existence of subfamilies Kerivoulinae and Murininae is well-supported. Subfamily Myotinae, earlier proposed by Simmons \& Gaisler (1998), was not recognized by other taxonomists until molecular evidence came along (Hoofer \& Van den Bussche, 2003; Hoofer et al., 2003). Antrozoidae, proposed by Simmons
\& Gaisler as a separate family, is now recognized as a tribe within Vespertilioninae s.str. (Roehrs et al., 2010; Amador et al., 2018).

Phylogenetic relationships within other families are partially reviewed in the following works: for Hipposideridae - Murray et al., 2012; Wilson et al., 2016; Foley et al., 2017; Patterson et al., 2020; Yusefovich et al., 2020; for Molossidae - Lamb et al., 2011; Ammerman et al., 2012; Reardon et al., 2014; Gregorin \& Cirranello, 2016.

A more or less consistent modern chiropteran system, thus, looks as follows. Number of accepted living genera in each taxon is shown in parentheses after symbol \#.

\section{Order Chiroptera \\ Suborder Yinpterochiroptera (=Pteropodiformes) Superfamily Pteropodoidea \\ Family Pteropodidae \\ (subfamilies Pteropodinae: Pteropodini (\#4),} Melonycterini (\#2), Pteralopini (\#3); Eidolinae (\#1); Rousettinae: Rousettini (\#1), Eonycterini (\#1), Epomophorini (\#4), Myonycterini (\#2), Stenonycterini (\#1), Scotonycterini (\#2), Plerotini (\#1); Cynopterinae: Cynopterini (\#3), Balionycterini (\#11); Macroglossuinae (\#2); Harpyonycterinae: Harpyonycterini (\#2), Dobsoniini (\#2); Nyctimeninae (\#2), Notopterisinae (\#1)) Superfamily Rhinolophoidea

Family Rhinolophidae (\#1)

Family Hipposideridae (\#8)

Family Rhinonycteridae (\#4)

Family Megadermatidae (\#5)

Family Rhinopomatidae (\#1)

Family Craseonycteridae (\#1)

Suborder Yangochiroptera (=Vespertilioniformes) Superfamily incertae sedis

Family Myzopodidae (\#1) Superfamily Emballonuroidea

Family Nycteridae (\#1)

Family Emballonuridae (two tribes: Emballonurini (\#4), Diclidurini (\#8); which subsequently could be raised to subfamilies)

Family Taphozoidae (see comments above; \#2) Superfamily Noctilionoidea

Family Tyropteridae (\#1)

Family Furipteridae (\#2)

Family Mystacinidae (\#1)

Family Noctilionidae (\#1)

Family Mormoopidae (\#)

Family Phyllostomidae (subfamilies Macrotinae (\#1); Micronycterinae (\#2); Desmodontinae: Desmodontini(\#2), Diphyllini (\#1); Lonchorhininae (\#1); Phyllostominae: Macrophyllini (\#2), Phyllostomini (\#5), Vampyrini (\#3); Glossophaginae: Glossophagini (\#3), Brachyphyllini (\#3), Choeronycterini (\#7); Lonchophylinae: Lonchophyllini (\#4), Hsunycterini (\#1); Carolliinae (\#1); Glyphonycterinae (\#3); Rhinophyllinae (\#1); Stenoderminae: Sturnirini (\#1), Stenodermatini (\#19))

Superfamily Vespertilionoidea (sometimes divided into three superfamilies)

Family Natalidae (\#3) 
Family Molossidae (subfamilies Tomopeatinae (\#1),

Molossinae (\#20-21))

Family Miniopteridae (\#1)

Family Cistugidae (\#1)

Family Vespertilionidae (subfamilies Kerivoulinae (\#2); Murininae (\#3): Myotinae (\#3); Vespertilioninae: Vespertilionini (\#15-18), Pipistrellini (\#6), Nycticeiini s.l. (probably paraphyletic; \#11), Antrozoini (\#2-4), “Perimyotini"* (\#2), Scotophilini (\#1), Plecotini (\#5-6), Lasiurini (\#1-3), Vespertilioninae inc. sedis (\#2))

* - this name is already in use (Wilson \& Mittermeier, 2019), but actually have no formal description.

ACKNOWLEDGMENTS. The review was funded by the Russian Foundation for Basic Research (RFBR), project number 20-14-50244. The work was performed in line with State theme of the ZMMU No. 121032300105-0.

\section{References}

Agnarsson I., Zambrana-Torrelio C.M., Flores-Saldana N.P \& May-Collado L.J. 2011. A time-calibrated specieslevel phylogeny of bats (Chiroptera, Mammalia) // PLoS Currents Vol.3. P.RRN1212.

Akanni W.A., Wilkinson M., Creevey C.J., Foster P.G. \& Pisani D. 2015. Implementing and testing Bayesian and maximum-likelihood supertree methods in phylogenetics // Royal Society Open Science. Vol.2. No.8. P.140436.

Almeida F.C., Giannini N.P. \& Simmons N.B. 2016. The evolutionary history of the African fruit bats (Chiroptera: Pteropodidae) // Acta Chiropterologica. Vol.18. No.1. P.73-108.

Almeida F.C., Giannini N.P., DeSalle R. \& Simmons N.B. 2011. Evolutionary relationships of the Old World fruit bats (Chiroptera, Pteropodidae): another star phylogeny? // BMC Evolutionary Biology. Vol.11. P.1-17.

Almeida F.C., Giannini N.P., Simmons N.B. \& Helgen K.M. 2014. Each flying fox on its own branch: A phylogenetic tree for Pteropus and related genera (Chiroptera: Pteropodidae) // Molecular Phylogenetics and Evolution. Vol.77. P.83-95.

Almeida F.C., Simmons N.B. \& Giannini N.P. 2020. A species-level phylogeny of Old World fruit bats with a new higher-level classification of the family Pteropodidae // American Museum Novitates. No.3950. P.1-24.

Álvarez Y., Juste J., Tabares E., Garrido-Pertierra A., Ibáñez C. \& Bautista J.M. 1999. Molecular phylogeny and morphological homoplasy in fruitbats // Molecular Biology and Evolution. Vol.16. P.1061-1067.

Amador L.I., Moyers Arévalo R.L., Almeida F.C., Catalano S.A. \& Giannini N.P. 2018. Bat systematics in the light of unconstrained analyses of a comprehensive molecular supermatrix // Journal of Mammalian Evolution. Vol.25. P.37-70.

Ammerman L.K., Lee D.N., \& Tipps T.M. 2012. First molecular phylogenetic insights into the evolution of free-tailed bats in the subfamily Molossinae (Molossidae, Chiroptera) // Journal of Mammalogy. Vol.93. No.1. P.12-28.

Andriollo T., Ashrafi S., Arlettaz R. \& Ruedi M. 2018. Porous barriers? Assessment of gene flow within and among sympatric long-eared bat species // Ecology and Evolution. Vol.8. No.24. P.12841-12854.

Ao L., Mao X., Nei W., Gu X., Feng Q., Wang J., Su W., Wang Y., Volleth M. \& Yang F. 2007. Karyotypic evolution and phylogenetic relationships in the order Chiroptera as revealed by G-banding comparison and chromosome painting // Chromosome Research. Vol.15. P.257-267.

Appleton B.R., McKenzie J.A. \& Christidis L. 2004. Molecular systematics and biogeography of the bentwing bat complex Miniopterus schreibersii (Kuhl, 1817) (Chiroptera: Vespertilionidae) // Molecular Phylogenetics and Evolution. Vol.31. No.2. P.431-439.

Arita H.T., Vargas-Baron J. \& Villalobos F. 2014. Latitudinal gradients of genus richness and endemism and the diversification of New World bats // Ecography. Vol.37. P.1024-1033.

Avise J.C. \& Liu J.-X. 2011. On the temporal inconsistencies of Linnean taxonomic ranks // Biological Journal of the Linnean Society. Vol.102. P.707-714.

Bailey S.E., Mao X., Struebig M., Tsagkogeorga G., Csorba G., Heaney L.R., Sedlock J., Stanley W., Rouillard J.-M. \& Rossiter S.J. 2016. The use of museum samples for largescale sequence capture: a study of congeneric horseshoe bats (family Rhinolophidae) // Biological Journal of the Linnean Society. Vol.117. No.1. P.58-70.

Baker R.J. 1973. Comparative cytogenetics of the New World leaf-nosed bats (Phyllostomatidae) // Periodicum Biologorum. Vol.75. No.1. P.37-45.

Baker R.J. 1979. Karyology // Baker R.J., Jones J.K. \& Carter D.C. (eds.). Biology of Bats of the New World Family Phyllostomatidae. Part 3. Lubbock: Texas Tech Press. P.107-155.

Baker R.J. \& Bickham J.W. 1980. Karyotypic evolution in bats: evidence of extensive and conservative chromosomal evolution in closely related taxa // Systematic Biology. Vol.29. No.3. P.239-253.

Baker R.J. \& Bradley R.D. 2006. Speciation in mammals and the genetic species concept // Journal of Mammalogy. Vol.87. No.4. P.643-662.

Baker R.J., Hoofer S.R., Porter C.A. \& Van Den Bussche R.A. 2003. Diversification among New World leafnosed bats: an evolutionary hypothesis and classification inferred from digenomic congruence of DNA sequence // Occasional Papers, Museum of Texas Tech University. No.230. P.1-32.

Baker R.J., Solari S., Cirranello A. \& Simmons N.B. 2016. Higher level classification of phyllostomid bats with a summary of DNA synapomorphies // Acta Chiropterologica. Vol.18. No.1. P.1-38.

Benathar T.C.M., Nagamachi C.Y., Rodrigues L.R.R., O'Brien P.C.M., Ferguson-Smith M.A., Yang F. \& Pieczarka J.C. 2019. Karyotype, evolution and phylogenetic reconstruction in Micronycterinae bats with implications for the ancestral karyotype of Phyllostomidae // BMC Evolutionary Biology. Vol.19. P.e98.

Benda P., Gazaryan S. \& Vallo P. 2016. On the distribution and taxonomy of bats of the Myotis mystacinus morphogroup from the Caucasus region (Chiroptera: Vespertilionidae) // Turkish Journal of Zoology. Vol.40. P.842-863.

Bergmans W. 1997. Taxonomy and biogeography of African fruit bats (Mammalia, Megachiroptera) 5: The genera Lissonycteris Andersen, 1912, Myonycteris Matschie, 1899 
and Megaloglossus Pagenstecher, 1885; General remarks and conclusions; Annex: key to all species // Beaufortia. Vol.47. No.2. P.11-90.

Bickham J.W., McBee K. \& Schlitter D.A. 1986. Chromosomal variation among seven species of Myotis (Chiroptera, Vespertilionidae) // Journal of Mammalogy. Vol.67. No.4. P.746-750

Bilgin R., Gurun K., Maraci O., Furman A., Hulva P., Çoraman E., Lucan R.K., Bartonicka T. \& Horacek I. 2012. Syntopic occurrence in Turkey supports separate species status for Miniopterus schreibersii schreibersii and $M$. schreibersii pallidus (Mammalia: Chiroptera) // Acta Chiropterologica. Vol.14. No.2. P.279-290.

Borisenko A.V., Kruskop S.V. \& Ivanova N.V. 2008. A new mouse-eared bat (Mammalia: Chiroptera: Vespertilionidae) from Vietnam // Russian Journal of Theriology. Vol.7. No.2. P.57-69.

Bradley R.D. \& Baker R.J. 2001. A test of the genetic species concept: cytochrome- $b$ sequences and mammals // Journal of Mammalogy. Vol.82. No.4. P.960-973.

Bragg J.G., Potter S., Bi K. \& Moritz C. 2015. Exon capture phylogenomics: efficacy across scales of divergence // Molecular Ecology Resources. Vol.16. No.5. P.1059-1068.

Camacho J., Heyde A., Bhullar B.-A.S., Haelewaters D., Simmons N.B. \& Abzhanov A. 2019. Peramorphosis, an evolutionary developmental mechanism in Neotropical bat skull diversity // Developmental Dynamics. Vol.248. P.1129-1143.

Caraballo D.A., Montani M.E., Martnez L.M., Antoniazzi L.R., Sambrana T.C., Fernandez C., Cisterna D.M., Beltron F.J. \& Colombo V.C. 2020. Heterogeneous taxonomic resolution of cytochrome $b$ gene identification of bats from Argentina: Implications for field studies // PLoS ONE. Vol.15. No.12. P.e0244750.

Castañeda-Rico S., León-Paniagua L., Edwards C.W. \& Maldonado J.E. 2020. Ancient DNA from museum specimens and next generation sequencing help resolve the controversial evolutionary history of the critically endangered Puebla deer mouse // Frontiers in Ecology and Evolution. Vol.8. P.e94.

Centeno-Cuadros A., Razgour O., García-Mudarra J.L., Mingo-Casas P., Sandonís V., Redondo A., Ibáñez C., de Paz O., Martinez-Alós S., Suarez G.P., Echevarría J.E. \& Juste J. 2019. Comparative phylogeography and asymmetric hybridization between cryptic bat species // Journal of Zoological Systematics and Evolutionary Research. Vol.57. No.4. P.1004-1018.

Cirranello A., Simmons N.B., Solari S. \& Baker R.J. 2016. Morphological diagnoses of higher-level phyllostomid taxa (Chiroptera: Phyllostomidae) // Acta Chiropterologica. Vol.18. No.1. P.39-71.

Çoraman E., Dundarova H., Dietz C. \& Mayer F. 2020. Patterns of mtDNA introgression suggest population replacement in Palaearctic whiskered bat species // Royal Society Open Science. Vol.7. No.6. P.e191805.

Csorba G. \& Lee L.-L. 1999. A new species of vespertilionid bat from Taiwan and a revision of the taxonomic status of Arielulus and Thainycteris (Chiroptera: Vespertilionidae) // Journal of Zoology. Vol.248. P.361-367.

Czaplewski N., Person J., Boyd C. \& Emry R. 2019. A new species of bat (Chiroptera: Vespertilionidae) from the early
Oligocene global cooling period, Brule Formation, North Dakota, USA // Palaeovertebrata. Vol.42. No.2. P.e2.

Dávalos L.M. \& Russell A.L. 2014. Sex-biased dispersal produces high error rates in mitochondrial distance-based and tree-based species delimitation // Journal of Mammalogy. Vol.95. No.4. P.781-791.

Dávalos L.M., Velazco P.M., Warsi O.M., Smits P.D. \& Simmons N.B. 2014. Integrating incomplete fossils by isolating conflicting signal in saturated and non-independent morphological characters // Systematic Biology. Vol.63. No.4. P.582-600.

De Queiroz K. 2007. Species concepts and species delimitation // Systematic Biology. Vol.56. No.6. P.879-886.

Demos T.C., Webala P.W., Peterhans J.C.K., Goodman S.M., Bartonjo M. \& Patterson B.D. 2019. Molecular phylogenetics of slit-faced bats (Chiroptera: Nycteridae) reveal deeply divergent African lineages // Journal of Zoological Systematics and Evolutionary Research. Vol.57. No.4. P.1019-1038.

Dietz C., Gazaryan A., Papov G., Dundarova H. \& Mayer F. 2016. Myotis hajastanicus is a local vicariant of a widespread species rather than a critically endangered endemic of the Sevan lake basin (Armenia) // Mammalian Biology. Vol.81. P.518-522.

Dobson G.E. 1875. Conspectus of the suborders, families and genera of Chiroptera arranged according to their natural affinities // Annals and Magazine of Natural History. Vol.16. No.4. P.345-357.

Dool S.E. 2020. Conservation genetic studies in bats // Ortega J. \& Maldonado J. (eds.). Conservation Genetics in Mammals. Cham: Springer. P.29-62.

Edwards S.V. 2009. Is a new and general theory of molecular systematics emerging? // Evolution. Vol.63. No.1. P.1-19.

Eick G.N., Jacobs D.S. \& Matthee C.A. 2005. A nuclear DNA phylogenetic perspective on the evolution of echolocation and historical biogeography of extant bats (Chiroptera) // Molecular Biology and Evolution. Vol.22. No.9. P.1869-1886.

Eiting T.P. \& Gunnell G.F. 2009. Global completeness of the bat fossil record // Journal of Mammalian Evolution. Vol.16. P.151-173.

Ellegren H. 2004. Microsatellites: simple sequences with complex evolution // Nature Reviews Genetics. Vol.5. No.6. P.435-445.

Elshire R.J., Glaubitz J.C., Sun Q., Poland J.A., Kawamoto K., Buckler E.S. \& Mitchell S.E. 2011. A robust, simple genotyping-by-sequencing (GBS) approach for high diversity species // PLoS ONE. Vol.6. No.5. P.e19379.

Elworth R.A.L., Ogilvie H.A., Zhu J. \& Nakhleh L. 2019. Advances in computational methods for phylogenetic networks in the presence of hybridization // Warnow T. (ed.). Bioinformatics and Phylogenetics. Computational Biology, Vol.29. Cham: Springer International Publishing. P.317-360.

Evin A., Baylac M., Ruedi M., Mucedda M. \& Pons J.-M. 2008. Taxonomy, skull diversity and evolution in a species complex of Myotis (Chiroptera: Vespertilionidae): a geometric morphometric appraisal // Biological Journal of the Linnean Society. Vol.95. No.3. P.529-538.

Fedyk S. \& Ruprecht A.L. 1983. Chromosomes of some species of vespertilionid bats. II. Evolutionary relationships 
of plecotine bats // Acta Theriologica. Vol.28. No.10. P.171-182.

Foley N.M., Goodman S.M., Whelan C.V., Puechmaille S.J. \& Teeling E. 2017. Towards navigating the Minotaur's labyrinth: cryptic diversity and taxonomic revision within the speciose genus Hipposideros (Hipposideridae) // Acta Chiropterologica. Vol.19. No.1. P.1-18.

Foley N.M., Thong V.D., Soisook P., Goodman S.M., Armstrong K.N., Jacobs D.S., Puechmaille S.J. \& Teeling E.C. 2015. How and why overcome the impediments to resolution: lessons from rhinolophid and hipposiderid bats // Molecular Biology and Evolution. Vol.32. P.313-333.

Freeman P.W. 2000. Macroevolution in Microchiroptera: recoupling morphology and ecology with phylogeny // Evolutionary Ecology Research. Vol.2. No.3. P.317-335.

Gager Y., Tarland E., Lieckfeldt D., Ménage M., BoteroCastro F., Rossiter S.J., Kraus R.H.S., Ludwig A. \& Dechmann D.K.N. 2016. The value of molecular vs. morphometric and acoustic information for species identification using sympatric molossid bats // PLoS ONE. Vol.11. No.3. P.e0150780.

Garbino G.S.T., Lim B.K. \& Tavares V.C. 2020. Systematics of big-eyed bats, genus Chiroderma Peters, 1860 (Chiroptera: Phyllostomidae) // Zootaxa. Vol.4846. No.1. P.1-93.

Giménez A.L., Giannini N.P. \& Almeida F.C. 2019. Mitochondrial genetic differentiation and phylogenetic relationships of three Eptesicus (Histiotus) species in a contact zone in Patagonia // Mastozoologa Neotropical. Vol.26. No.2. P.349-358.

Gomes A.J.B., Nagamachi C.Y., Rodrigues L.R.R., Benathar T.C.M., Ribas T.F.A., O’Brien P.C.M., Yang F., Ferguson-Smith M.A. \& Pieczarka J.C. 2016. Chromosomal phylogeny of vampyressine bats (Chiroptera, Phyllostomidae) with description of two new sex chromosome systems // BMC Evolutionary Biology. Vol.16. P.e119.

Gomes A.J.B., Nagamachi C.Y., Rodrigues L.R.R., FergusonSmith M.A., Yang F., O’Brien P.C.M. \& Pieczarka J.C. 2018. Chromosomal evolution and phylogeny in the Nullicauda group (Chiroptera, Phyllostomidae): evidence from multidirectional chromosome painting // BMC Evolutionary Biology. Vol.18. P.e62.

Gomes A.J.B., Rodrigues L.R.R., Rissino J.D., Nagamachi C.Y. \& Pieczarka J.C. 2010. Biogeographical karyotypic variation of Rhinophylla fischerae (Chiroptera: Phyllostomidae) suggests the occurrence of cryptic species // Comparative Cytogenetics. Vol.4. P.9-85.

Goodman S.M., Puechmaille S.J., Friedli-Weyeneth N., Gerlach J., Ruedi M., Schoeman M.C., Stanley W.T. \& Teeling E.C. 2012. Phylogeny of the Emballonurini (Emballonuridae) with descriptions of a new genus and species from Madagascar// Journal of Mammalogy. Vol.93. No.6. P.1440-1455.

Gorobeyko U., Kartavtseva I., Sheremetyeva I., Kazakov D. \& Guskov V. 2020. DNA-barcoding and a new data about the karyotype of Myotis petax (Chiroptera, Vespertilionidae) in the Russian Far East // Comparative Cytogenetics. Vol.14. P.483-500.

Görföl T., Estok P. \& Csorba G. 2013. The subspecies of Myotis montivagus - taxonomic revision and species limits (Mammalia: Chiroptera: Vespertilionidae) // Acta
Zoologica Academiae Scientiarum Hungaricae. Vol.59. No.1. P.41-59.

Graphodatsky A., Ferguson-Smith M.A. \& Stanyon R. 2012. A short introduction to cytogenetic studies in mammals with reference to the present volume // Cytogenetic and Genome Research. Vol.137. No.2-4. P.83-96.

Gregorin R. \& Cirranello A. 2016. Phylogeny of Molossidae Gervais (Mammalia: Chiroptera) inferred by morphological data // Cladistics. Vol.32. P.2-35.

Gunnell G.F. \& Simmons N.B. 2005. Fossil evidence and the origin of bats // Journal of Mammalian Evolution. Vol.12. P.209-246.

Gunnell G.F., Jacobs B.F., Herendeen P.S., Head J.J., Kowalski E., Msuya C.P., Mizabwa F.A., Harrison T., Hebersetzer J. \& Storch G. 2005. Oldest placental mammal from sub-Saharan Africa: Eocene microbat from Tanzania - evidence for early evolution of sophisticated echolocation // Palaeontologia Electronica. Vol.5. P.1-10.

Gunnell G.F., Simmons N.B. \& Seiffert E.R. 2014. New Myzopodidae (Chiroptera) from the Late Paleogene of Egypt: emended family diagnosis and biogeographic origins of Noctilionoidea // PLoS ONE. Vol.9. No.2. P.e86712.

Gunnell G.F., Simons E.L. \& Seiffert E.R. 2008. New bats (Mammalia: Chiroptera) from the late Eocene and early Oligocene, Fayum Depression, Egypt // Journal of Vertebrate Paleontology. Vol.28. P.1-11

Gunnell G.F., Smith R. \& Smith T. 2017. 33 million year old Myotis (Chiroptera, Vespertilionidae) and the rapid global radiation of modern bats // PLoS ONE. Vol.12. No.3. P.e0172621.

Habersetzer J., Schlosser-Sturm E., Storch G. \& Sigé B. 2012. Shoulder joint and inner ear of Tachypteron franzeni, an emballonurid bat from the Middle Eocene of Messel // Gunnell G.F. \& Simmons N.B. (eds.). Evolutionary History of Bats: Fossils, molecules and Morphology. Cambridge: Cambridge University Press. P.67-104.

Hand S.J., Sigé B., Archer M. \& Black K.H. 2016. An evening bat (Chiroptera: Vespertilionidae) from the late Early Eocene of France, with comments on the antiquity of modern bats // Palaeovertebrata. Vol.40. No.2. P.e2.

Hassanin A., Colombo R., Tungaluna G.-C., Merle M., Tu V.T., Görföl T., Akawa P., Csorba G., Kearney T., Monadjem A. \& Ing R. 2017. Multilocus phylogeny and species delimitation within the genus Glauconycteris (Chiroptera, Vespertilionidae), with the description of a new bat species from the Tshopo Province of the Democratic Republic of the Congo // Journal of Zoological Systematics and Evolutionary Research. Vol.56. P.1-22.

Hassanin A., Bonillo C., Tshikung D., Pongombo Shongo C., Pourrut X., Kadjo B., Nakouné E., Tu V.T., Prié V. \& Goodman S.M. 2020. Phylogeny of African fruit bats (Chiroptera, Pteropodidae) based on complete mitochondrial genomes // Journal of Zoological Systematics and Evolutionary Research. Vol.58. No.4. P.1395-1410.

Hawkins J.A., Kaczmarek M.E., Müller M.A., Drosten C., Press W.H. \& Sawyer S.L. 2019. A metaanalysis of bat phylogenetics and positive selection based on genomes and transcriptomes from 18 species // Proceedings of the National Academy of Sciences of the USA. Vol.116. No.23. P.11351-11360 
Hedrick B.P. \& Dumont E. 2018. Putting the leaf-nosed bats in context: A geometric morphometric analysis of three of the largest families of bats // Journal of Mammalogy. Vol.99. No.5. P.1042-1054.

Hedrick B.P., Mutumi G.L., Munteanu V.D., Sadier A., Davies K.T.J., Rossiter S.J., Sears K.E., Dávalos L.M. \& Dumont E. 2020. Morphological diversification under high integration in a hyper diverse mammal clade // Journal of Mammalian Evolution. Vol.27. P.563-575.

Heller K.-G. \& Volleth M. 1984. Taxonomic position of "Pipistrellus societatis" Hill, 1972 and the karyological characteristics of the genus Eptesicus (Chiroptera: Vespertilionidae)// Journal of Zoological Systematics and Evolutionary Research. Vol.22. P.65-77.

Hill J.E. 1974. A new family, genus and species of bat (Mammalia; Chiroptera) from Thailand // Bulletin of the British Museum (Natural History), Zoology. Vol.27. P.301-336.

Hoffmann F.G., Hoofer S.R. \& Baker R.J. 2008. Molecular dating of the diversification of Phyllostominae bats based on nuclear and mitochondrial DNA sequences // Molecular Phylogenetics and Evolution. Vol.49. No.2. P.653-658.

Hollar L.J. \& Springer M.S. 1997. Old World fruit bat phylogeny: evidence for convergent evolution and an endemic African clade // Proceedings of the National Academy of Science of the USA. Vol.94. P.5716-5721.

Hood C.S., Schlitter D.A., Georgudaki J.I., Yenbutra S. \& Baker R.J. 1988. Chromosomal studies of bats (Mammalia: Chiroptera) from Thailand // Annals of Carnegie Museum. Vol.57. P.99-109.

Hoofer S.R. \& Van den Bussche R.A. 2001. Phylogenetic relationships of plecotine bats and allies based on mitochondrial ribosomal sequences // Journal of Mammalogy. Vol.82. No.1. P.131-137.

Hoofer S.R. \& Van den Bussche R.A. 2003. Molecular phylogenetics of the chiropteran family Vespertilionidae // Acta Chiropterologica. Vol.5. Suppl.1. P.1-63.

Hoofer S.R., Reeder S.A., Hansen E.W. \& Van Den Bussche R.A. 2003. Molecular phylogenetics and taxonomic review of noctilionoid and vespertilionoid bats (Chiroptera: Yangochiroptera) // Journal of Mammalogy. Vol.84. No.3. P.809-821.

Horaček I. \& Hanak V. 1986. Generic status of Pipistrellus savii and comments on classification of the genus Pipistrellus (Chiroptera, Vespertilionidae)// Myotis. Vol.23-24. P.9-16.

Horáček I., Fejfar O. \& Hulva P. 2006. A new genus of vespertilionid bat from early Miocene of Jebel Zelten, Libya, with comments on Scotophilus and early history of vespertilionid bats (Chiroptera) // Lynx. Vol.37. P.131-150.

Huang C., Yu W., Xu Z., Qiu Y., Chen M., Qiu B., Motokawa M., Harada M., Li Y. \& Wu Y. 2014. A cryptic species of the Tylonycteris pachypus complex (Chiroptera: Vespertilionidae) and its population genetic structure in southern China and nearby regions // International Journal of Biological Sciences. Vol.10. No.2. P.200-211.

Huang J., Liu Y., Zhu T. \& Yang Z. 2020. The asymptotic behavior of bootstrap support values in molecular phylogenetics // Systematic Biology. Vol.70. No.4. P.774-785.

Hulva P. \& Horáček I. 2002. Craseonycteris thonglongyai (Chiroptera: Craseonycteridae) is a rhinolophoid: molecular evidence from cytochrome $b$ // Acta Chiropterologica. Vol.4. No.2. P.107-120.

Hulva P., Horáček I. \& Benda P. 2007. Molecules, morphometrics and new fossils provide an integrated view of the evolutionary history of Rhinopomatidae (Mammalia: Chiroptera) // BMC Evolutionary Biology. Vol.7. P.165.

Hulva P., Fornůsková A., Chudárková A., Evin A., Allegrini B., Benda P. \& Bryja J. 2010. Mechanisms of radiation in a bat group from the genus Pipistrellus inferred by phylogeography, demography and population genetics // Molecular Ecology. Vol.19. No.24. P.5417-5431.

Hutcheon J.M. \& Kirsch J.A.W. 2004. Camping in a different tree: results of molecular systematic studies of bats using DNA-DNA hybridization // Journal of Mammalian Evolution. Vol.11. No.1. P.17-47.

Hutcheon J.M. \& Kirsch J.A.W. 2006. A moveable face: deconstructing the Microchiroptera and a new classification of extant bats // Acta Chiropterologica. Vol.8. No.1. P.1-10.

Hutterer R., Decher J., Monadjem A. \& Astrin J. 2019. A new genus and species of vesper bat from West Africa, with notes on Hypsugo, Neoromicia, and Pipistrellus (Chiroptera: Vespertilionidae) // Acta Chiropterologica. Vol.21. No.1. P.1-22.

Igea J., Juste J. \& Castresana J. 2010. Novel intron markers to study the phylogeny of closely related mammalian species // BMC Evolutionary Biology. Vol.10. No.1. P.e369.

Ivanova N.V., Clare E.L. \& Borisenko A.V. 2012. DNA barcoding in mammals // Kress W.J. \& Erickson D.L. (eds.). DNA Barcodes: Methods and Protocols. Methods in Molecular Biology. Vol.858. Humana Press. P.153-182.

Jacobs D.S., Eick G.N., Schoeman M.C. \& Matthee C.A. 2006. Cryptic species in an insectivorous bat, Scotophilus dinganii // Journal of Mammalogy. Vol.87. No.1. P.161170.

Jarrín-V P. \& Kunz T.H. 2011. A new species of Sturnira (Chiroptera: Phyllostomidae) from the Choco forest of Ecuador // Zootaxa. Vol.2755. No.1. P.1-35.

Jones G. \& Teeling E.C. 2006. The evolution of echolocation in bats // Trends in Ecology and Evolution. Vol.21. No.3. P.149-156.

Juste J., Álvarez Y., Tabarés E., Garrido-Pertierra A., Ibáñez C. \& Bautista J.M. 1999. Phylogeography of African fruit bats (Megachiroptera) // Molecular Phylogenetics and Evolution. Vol.13. P.596-604.

Kawai K., Nikaido M., Harada M., Matsumura S., Lin L. K., Wu Y., Hasegawa M. \& Okada N. 2003. The status of the Japanese and East Asian bats of the genus Myotis (Vespertilionidae) based on mitochondrial sequences // Molecular Phylogenetics and Evolution. Vol.28. No.2. P.297-307.

Kearney T.C., Volleth M., Contrafatto G. \& Taylor P.J. 2002. Systematic implications of chromosome GTG-band and bacula morphology for southern African Eptesicus and Pipistrellus and several other species of Vespertilioninae (Chiroptera: Vespertilionidae) // Acta Chiropterologica. Vol.4. No.1. P.55-76.

Khan F.A.A., Solari S., Swier V.J., Larsen P.A., Abdullah M. \& Baker R.J. 2010. Systematics of Malaysian woolly bats (Vespertilionidae: Kerivoula) inferred from mitochondrial, nuclear, karyotypic, and morphological data // Journal of Mammalogy. Vol.91. No.5. P.1058-1072. 
Kirsch J.A.W., Flannery T.F., Springer M.S. \& Lapointe F.-J. 1995. Phylogeny of the Pteropodidae (Mammalia: Chiroptera) based on DNA hybridisation, with evidence for bat monophyly // Australian Journal of Zoology. Vol.43. No.4. P.395-428.

Koopman K.F. 1984. Bats // Anderson S. \& Jones Jr. J.K. (eds.). Orders and Families of Recent Mammals of the World. New York: Wiley-Interscience. P.145-186.

Koopman K.F. 1993. Order Chiroptera // Wilson D.E. \& Reeder D.M. (eds.). Mammal Species of the World, a Taxonomic and Geographic Reference. Second edition. Washington: Smithsonian Institution Press. P.137-241.

Koopman K.F. 1994. Chiroptera: Systematics, VIII. Mammalia, part 60. New York: Walter de Gruyter. 217 p.

Koubínová D., Irwin N., Hulva P., Koubek P. \& Zima J. 2013. Hidden diversity in Senegalese bats and associated findings in the systematics of the family Vespertilionidae // Frontiers in Zoology. Vol.10. P.e48.

Ksepka D.T., Parham J.F., Allman J.F., Benton M.J., Carrano M.T., Cranston K.A., Donoghue P.C.J., Head J.J., Hermsen E.J., Irmis R.B., Joyce W.G., Kohli M., Lamm K.D., Leehr D., Patané J.L., Polly P.D., Phillips M.J., Smith N.A., Smith N.D., Van Tuinen M., Ware J.L. \& Warnock R.C.M. 2015. The fossil calibration database - a new resource for divergence dating // Systematic Biology. Vol.64. No.5. P.853-859.

Lack J.B. \& Van Den Bussche R.A. 2010. Identifying the confounding factors in resolving phylogenetic relationships in Vespertilionidae // Journal of Mammalogy. Vol.91. No.6. P.1435-1448

Lack J.B., Roehrs Z.P., Stanley C.E., Ruedi M. \& Van Den Bussche R.A. 2010. Molecular phylogenetics of Myotis indicate familial-level divergence for the genus Cistugo (Chiroptera) // Journal of Mammalogy. Vol.91. No.4. P.976-992.

Lamb J.M., Ralph T.M.C., Naidoo T., Taylor P.J., Ratrimomanarivo F., Stanley W.T. \& Goodman S.M. 2011. Toward a molecular phylogeny for the Molossidae (Chiroptera) of the Afro-Malagasy region // Acta Chiropterologica. Vol.13. No.1. P.1-16.

Leaché A.D., Harris R.B., Rannala B. \& Yang Z. 2013 The influence of gene flow on species tree estimation: a simulation study // Systematic Biology. Vol.63. No.1. P.17-30.

Lei M. \& Dong D. 2016. Phylogenomic analyses of bat subordinal relationships based on transcriptome data // Scientific Reports. Vol.6. No.1. P.e27726.

Li C., Hofreiter M., Straube N., Corrigan S. \& Naylor G.J. 2013. Capturing protein-coding genes across highly divergent species // BioTechniques. Vol.54. No.6. P.321-326.

Loureiro L.O., Engstrom M.D. \& Lim B.K. 2020. Single nucleotide polymorphisms (SNPs) provide unprecedented resolution of species boundaries, phylogenetic relationships, and genetic diversity in the mastiff bats (Molossus) // Molecular Phylogenetics and Evolution. Vol.143. P.e106690.

Maitre E. 2014. Western European middle Eocene to lower Oligocene Chiroptera - systematics, phylogeny and palaeoecology based on new material from the Quercy (France) // Swiss Journal of Palaeontology. Vol.133. P.141-242.

Mao X. \& Rossiter S.J. 2020. Genome-wide data reveal discordant mitonuclear introgression in the intermediate horseshoe bat (Rhinolophus affinis) // Molecular Phylogenetics and Evolution. Vol.150. P.e106886.

Mao X., Tsagkogeorga G., Thong V.D. \& Rossiter S.J. 2019. Resolving evolutionary relationships among six closely related taxa of the horseshoe bats (Rhinolophus) with targeted resequencing data // Molecular Phylogenetics and Evolution. Vol.139. P.e106551.

Marcus L., Hingst-Zaher E. \& Zaher H. 2000. Application of landmark morphometrics to skulls representing the orders of living mammals // Hystrix. Vol.11. No.1. P.27-47.

Matveev V.A., Kruskop S.V. \& Kramerov D.A. 2005. Revalidation of Myotis petax Hollister, 1912 and its new status in connection with Myotis daubentonii (Kuhl, 1817) (Vespertilionidae, Chiroptera) // Acta Chiropterologica. Vol.7. No.1. P.23-37.

Mayer F., Dietz C. \& Kiefer A. 2007. Molecular species identification boosts bat diversity // Frontiers in Zoology. Vol.4. No.1. P.e4.

McKenna M.C. \& Bell S.K. 1997. Classification of Mammals Above the Species Level. New York: Columbia University Press. 631 p.

Mein P. \& Tupinier Y. 1977. Formule dentaire et position systematique du minioptere (Mammalia, Chiroptera) // Mammalia. Vol.41. No.2. P.207-211.

Méndez-Rodrguez A., Juste J., Centeno-Cuadros A., RodrguezGymezF., Serrato-DazA., Garca-Mudarra J.L., Guevara-Chumacero L.M. \& Lypez-Wilchis R. 2021. Genetic introgression and morphological variation in naked-back bats (Chiroptera: Mormoopidae: Pteronotus species) along their contact zone in Central America // Diversity. Vol.13. No.5. P.194.

Menu H. \& Sigé B. 1971. Nyctalodontie et myotodontie, importants caractères de grades évolutifs chez les chiroptères entomophages // Comptes Rendus de l'Académie des Sciences Paris. Vol.272. P.1735-1738.

Menu H. 1987. Morphotypes dentaires actuels et fossiles des chiropteres // Palaeovertebrata. Vol.17. P.77-150.

Meredith R.W., Janečka J., Gatesy J., Ryder O., Fisher C., Teeling E., Goodbla A., Eizirik E., Simao T., Stadler T., Rabosky D., Honeycutt R., Flynn J., Ingram C., Steiner C., Williams T., Robinson T., Burk-Herrick A., Westerman M. \& Murphy W. 2011. Impacts of the Cretaceous terrestrial revolution and KPg extinction on mammal diversification // Science. Vol.334. No.6055. P.521-524.

Miller G.S. 1907. The families and genera of bats // Bulletin of the Smithsonian Institution, United States National Museum. Vol.57. P.1-282.

Miller-Butterworth C., Murphy W., O'Brien S., Jacobs D., Springer M. \& Teeling E. 2007. A family matter: Conclusive resolution of the taxonomic position of the long-fingered bats, Miniopterus // Molecular Biology and Evolution. Vol.24. No.7. P.1553-1561.

Miller-Butterworth C.M., Eick G., Jacobs D.S., Schoeman M.C. \& Harley E.H. 2005. Genetic and phenotypic differences between South African long-fingered bats, with a global miniopterine phylogeny // Journal of Mammalogy. Vol.86. No.6. P.1121-1135.

Molloy E.K. \& Warnow T. 2017. To include or not to include: the impact of gene filtering on species tree estimation methods // Systematic Biology. Vol.67. No.2. P.285-303.

Monadjem A., Demos T.C., Dalton D.L., Webala P.W., Musila S., Kerbis Peterhans J.C. \& Patterson B.D. 2021. 
A revision of pipistrelle-like bats (Mammalia: Chiroptera: Vespertilionidae) in East Africa with the description of new genera and species // Zoological Journal of the Linnean Society. Vol.191. No.4. P.1114-1146.

Morales A.E. \& Carstens B.C. 2018. Evidence that Myotis lucifugus subspecies are five nonsister species, despite gene flow // Systematic Biology. Vol.67. No.5. P.756-769.

Morales A.E., Jackson N.D., Dewey T.A., O'Meara B.C. \& Carstens B.C. 2016. Speciation with gene flow in North American Myotis bats // Systematic Biology. Vol.66. No.3. P.440-452.

Murray S.W., Campbell P., Kingston T., Zubaid A., Francis C.M. \& Kunz T.H. 2012. Molecular phylogeny of hipposiderid bats from Southeast Asia and evidence of cryptic diversity // Molecular Phylogenetics and Evolution. Vol.62. P.597-611.

Nachman M.W. 2013. Genomics and museum specimens // Molecular Ecology. Vol.22. P.5966-5968.

Nelson-Rees W.A., Kniazeff A.J., Baker R.J. \& Patton J.L. 1968. Intraspecific chromosome variation in the bat, Macrotus waterhousii Gray // Journal of Mammalogy. Vol.49. No.4. P.706-712.

Nesi N., Tsagkogeorga G., Tsang S., Nicolas V., Lalis A., Scanlon A., Riesle S., Wiantoro S., Hitch A., Juste J., Pinzari C., Bonaccorso F., Todd C., Lim B., Simmons N., McGowen M. \& Rossiter S. 2021. Interrogating phylogenetic discordance resolves deep splits in the rapid radiation of Old World fruit bats (Chiroptera: Pteropodidae) // Systematic Biology. doi: 10.1093/sysbio/syab013

Nojiri T., Wilson L.A.B., López-Aguirre C., Tu V.T., Kuratani S., Ito K., Higashiyama H., Son N.T., Fukui D., Sadier A., Sears K.E., Endo H., Kamihori S. \& Koyabu D. 2021. Embryonic evidence uncovers convergent origins of laryngeal echolocation in bats // Current Biology. Vol.31. No.7. P.1353-1365.

O’Toole B., Simmons N.B. \& Hekkala E. 2021. Reconstructing the genomic diversity of a widespread Sub-Saharan bat (Pteropodidae: Eidolon helvum) using archival museum collections // Acta Chiropterologica. Vol.22. No.2.P.227-241.

Padial J.M., Miralles A., De la Riva I. \& Vences M. 2010. The integrative future of taxonomy // Frontiers in Zoology. Vol.7. No.16. P.1-14.

Parlos J.A., Timm R.M., Swier V.J., Zeballos H. \& Baker R.J. 2014. Evaluation of the paraphyletic assemblage within Lonchophyllinae, with description of a new tribe and genus // Occasional Papers, Museum of Texas Tech University. No.320. P.1-23.

Patterson B.D., Webala P.W., Lavery T.H., Agwanda B.R., Goodman S.M., Kerbis Peterhans J.C. \& Demos T.C. 2020. Evolutionary relationships and population genetics of the Afrotropical leaf-nosed bats (Chiroptera, Hipposideridae) // Zookeys. Vol.929. P.117-161.

Petri B., von Haeseler A. \& Pääbo S. 1996. Extreme sequence heteroplasmy in bat mitochondrial DNA // Biological Chemistry Hoppe-Seyler. Vol.377. No.10. P.661-668.

Philippe H., Brinkmann H., Lavrov D.V., Littlewood D.T.J., Manuel M., Wörheide G. \& Baurain D. 2011. Resolving difficult phylogenetic questions: why more sequences are not enough // PLoS Biology. Vol.9. No.3. P.e1000602.

Porter C.A., Hoofer S.R., Cline C.A., Hoffmann F.G. \& Baker R.J. 2007. Molecular phylogenetics of the phyllostomid bat genus Micronycteris with descriptions of two new subgenera // Journal of Mammalogy. Vol.88. No.5. P.1205-1215.

Ravel A., Adaci M., Bensalah M., Charruault A.-L., Essid E.M., Ammar H.K., Marzougui W., Mahboubi M., Mebrouk F., Merzeraud G., Vianney-Liaud M., Tabuce R. \& Marivaux L. 2016. Origine et radiation initiale des chauves-souris modernes: nouvelles découvertes dans l'Éocène d'Afrique du Nord // Geodiversitas. Vol.38. No.3. P.355-434.

Ravel A., Marivaux L., Qi T., Wang Y.-Q. \& Beard K.C. 2014. New chiropterans from the middle Eocene of Shanghuang (Jiangsu Province, Coastal China): new insight into the dawn horseshoe bats (Rhinolophidae) in Asia // Zoologica Scripta. Vol.43. No.1. P.1-23.

Reardon T.B., McKenzie N.L., Cooper S.J.B., Appleton B., Carthew S., \& Adams M. 2014. A molecular and morphological investigation of species boundaries and phylogenetic relationships in Australian free-tailed bats Mormopterus (Chiroptera: Molossidae) // Australian Journal of Zoology. Vol.62. No.2. P.109-136.

Reeder D.M., Helgen K.M., Vodzak M.E., Lunde D.P. \& Ejotre I. 2013. A new genus for a rare African vespertilionid bat: Insights from South Sudan // Zookeys. Vol.285. P.89-115.

Roehrs Z.P., Lack J.B. \& Van Den Bussche R.A. 2010. Tribal phylogenetic relationships within Vespertilioninae (Chiroptera: Vespertilionidae) based on mitochondrial and nuclear sequence data // Journal of Mammalogy. Vol.91. No.5. P.1073-1092.

Roehrs Z.P., Lack J.B. \& Van den Bussche R.A. 2011. A molecular phylogenetic reevaluation of the tribe Nycticeini (Chiroptera: Vespertilionidae) // Acta Chiropterologica. Vol.13. No.1. P.17-31.

Romagnoli M.L. \& Springer M.S. 2000. Evolutionary relationships among Old World fruitbats (Megachiroptera: Pteropodidae) based on 12S rRNA, tRNA Valine, and 16S rRNA gene sequences // Journal of Mammalian Evolution. Vol.7. No.4. P.259-284.

Rosina V.V. \& Rummel M. 2012. The bats (Chiroptera, Mammalia) from the Early Miocene of Petersbuch (Bavaria, Southern Germany) // Geobios. Vol.45. No.5. P.463-478.

Rosina V.V., Kruskop S.V. \& Semenov Y.V. 2019. New late Miocene plecotine bats (Chiroptera, Vespertilionidae: Plecotini) from Gritsev, Ukraine // Palaeovertebrata. Vol.42. No.1. P.1-13.

Rossoni D.M., Costa B.M.A., Giannini N.P. \& Marroig G. 2019. A multiple peak adaptive landscape based on feeding strategies and roosting ecology shaped the evolution of cranial covariance structure and morphological differentiation in phyllostomid bats // Evolution. Vol.73. P.961-981.

Ruedi M. \& Mayer F. 2001. Molecular systematics of bats of the genus Myotis (Vespertilionidae) suggests deterministic ecomorphological convergences // Molecular Phylogenetics and Evolution. Vol.21. No.3. P.436-448.

Ruedi M., Stadelmann B., Gager Y., Douzery E.J.P., Francis C.M., Lin L.-K., Guillen-Servent A. \& Cibois A. 2013. Molecular phylogenetic reconstructions identify East Asia as the cradle for the evolution of the cosmopolitan 
genus Myotis (Mammalia, Chiroptera) // Molecular Phylogenetics and Evolution. Vol.69. P.437-449.

Ruedi M., Friedli-Weyeneth N., Teeling E.C., Puechmaille S.J. \& Goodman S.M. 2012. Biogeography of Old World emballonurine bats (Chiroptera: Emballonuridae) inferred with mitochondrial and nuclear DNA // Molecular Phylogenetics and Evolution. Vol.64. No.1. P.204-211.

Schmieder D.A., Benítez H.A., Borissov I.M. \& Fruciano C. 2015. Bat species comparisons based on external morphology: a test of traditional versus geometric morphometric approaches // PLoS ONE. Vol.10. No.5. P.e0127043.

Sigé B. 1991. Morphologie dentaire lacteale d'un chiroptere de l'Eocene inferieur-moyen d'Europe // Geobios. Vol.13. P.231-236.

Sigé B., Mein P., Jousse H. \& Aguilar J.-P. 2014. Un nouveau Rhinopomatidae (Chiroptera) du Paléokarst miocène de Baixas (Pyrénées-Orientales, France); apport zoogéographique // Geodiversitas. Vol.36. No.2. P.257-281.

Simmons N.B. \& Geisler J.B. 1998. Phylogenetic relationships of Icaronycteris, Archaeonycteris, Hassianycteris, and Palaeochiropteryx to extant bat lineages, with comments on the evolution of echolocation and foraging strategies in Microchiroptera // Bulletin of the American Museum of Natural History. Vol.235. P.1-182.

Simmons N.B. 1995. Bat relationships and the origin of flight// Racey P.A. \& Swift S.M. (eds.). Ecology, Evolution, and Behavior of Bats. Symposium of Zoological Society of London. Vol.67. Oxford: Oxford University Press. P.27-43.

Simmons N.B. 1998. A reappraisal of interfamilial relationships of bats // Kunz T.H. \& Racey P.A. (eds.). Bat Biology and Conservation. Washington: Smithsonian Institution Press. P.3-26.

Simmons N.B. 2005. Order Chiroptera // Wilson D.E. \& Reeder D.M. (eds.). Mammal Species of the World: a Taxonomic and Geographic Reference. Third edition. Baltimore: Johns Hopkins University Press. P.312-529.

Simmons N.B., Seymour K.L., Habersetzer J. \& Gunnell G.F. 2008. Primitive early Eocene bat from Wyoming and the evolution of flight and echolocation // Nature. Vol.451. P.818-822.

Smith J.D. \& Madkour G. 1980. Penial morphology and the question of chiropteran phylogeny // Wilson D.E. \& Gardner A.L. (eds.). Proceedings of Fifth International Bat Research Conference. Lubbock: Texas Tech Press. P.347-365.

Smith T., Rana R.S., Missiaen P., Rose K.D., Sahni A., Singh H. \& Singh L. 2007. High bat (Chiroptera) diversity in the early Eocene of India // Naturwissenschaften. Vol.94. P.1003-1009.

Solari S. \& Baker J.R. 2006. Mitochondrial DNA sequence, karyotypic, and morphological variation in the Carollia castena species complex (Chiroptera: Phyllostomidae) with description of a new species // Occasional Papers of Texas Tech University Museum. No.254. P.1-16.

Solari S., Sotero-Caio C.G. \& Baker R.J. 2019. Advances in systematics of bats: towards a consensus on species delimitation and classifications through integrative taxonomy // Journal of Mammalogy. Vol.100. No.3. P.838-851.

Sotero-Caio C.G., Baker R.J. \& Volleth M. 2017. Chromosomal Evolution in Chiroptera // Genes. Vol.8. No.10. P.272.

Spitzenberger F., Strelkov P.P., Winkler H. \& Haring E. 2006. A preliminary revision of the genus Plecotus (Chiroptera,
Vespertilionidae) based on genetic and morphological results // Zoologica Scripta. Vol.35. No.3. P.187-230.

Springer M., Meredith R., Eizirik E., Teeling E. \& Murphy W. 2008. Morphology and placental mammal phylogeny // Systematic Biology. Vol.57. P.499-503.

Springer M., Teeling E., Madsen O., Stanhope M. \& Jong W. 2001. Integrated fossil and molecular data reconstruct bat echolocation // Proceedings of the National Academy of Sciences of the USA. Vol.98. P.6241-6246.

Sramek J., Gvozdik V. \& Benda P. 2013. Hidden diversity in bent-winged bats (Chiroptera: Miniopteridae) of the Western Palaearctic and adjacent regions: implications for taxonomy // Zoological Journal of the Linnean Society. Vol.167. P.165-190.

Storch G., Sigé B. \& Habersetzer J. 2002. Tachypteron franzeni n. gen., n. sp., earliest emballonurid bat from the Middle Eocene of Messel (Mammalia, Chiroptera) // Paläontologische Zeitschrift. Vol.76. No.2. P.189-199.

Sun K., Feng J., Zhang Z., Xu L. \& Liu Y. 2009. Cryptic diversity in Chinese rhinolophids and hipposiderids (Chiroptera: Rhinolophidae and Hipposideridae) // Mammalia. Vol.73. No.2. P.135-141.

Sztencel-Jabłonka A., Jones G. \& Bogdanowicz W. 2009. Skull morphology of two cryptic bat species: Pipistrellus pipistrellus and P. pygmaeus - a 3D geometric morphometrics approach with landmark reconstruction // Acta Chiropterologica. Vol.11. No.1. P.113-126.

Sztencel-Jabłonka A. \& Bogdanowicz W. 2012. Population genetics study of common (Pipistrellus pipistrellus) and soprano (Pipistrellus pygmaeus) pipistrelle bats from Central Europe suggests interspecific hybridization // Canadian Journal of Zoology. Vol.90. No.10. P.1251-1260.

Tate G.H.H. 1941a. A review of the genus Myotis (Chiroptera) of Eurasia, with special reference to species occuring in the East Indies // Bulletin of the American Museum of Natural History. Vol.78.No.8. P.537-565.

Tate G.H.H. 1941b. A review of the genus Hipposideros with special reference to Indo-Australian species // Bulletin of the American Museum of Natural History. Vol.78. No.5. P.353-393.

Tate G.H.H. 1941c. Notes on Vespertilionid bats of the subfamilies Miniopterinae, Murininae, Kerivoulinae, and Nyctophilinae // Bulletin of the American Museum of Natural History. Vol.78. No.9. P.567-597.

Tate G.H.H. 1942. Review of the vespertilionine bats, with special attention to genera and species of the Archbold collections // Bulletin of the American Museum of Natural History. Vol.80. No.7. P.221-297.

Teeling E.C. 2009. Hear, hear: the convergent evolution of echolocation in bats? // Trends in Ecology and Evolution. Vol.24. No.7. P.351-354.

Teeling E.C., Jones G. \& Rossiter S.J. 2016. Phylogeny, genes, and hearing: implications for the evolution of echolocation in bats // Fenton M.B., Grinnell A.D. \& Popper A.N. (eds.). Bat Bioacoustics. New York: Springer. P.25-54.

Teeling E.C., Madsen O., Murphey W.J., Springer M.S. \& O'Brien S.J. 2003. Nuclear gene sequences confirm an ancient link between New Zealand short-tailed bat and South American noctilionoid bats // Molecular Phylogenetics and Evolution. Vol.28. P.308-319.

Teeling E.C., Madsen O., Van Den Bussche R.A., de Jong W.W., Stanhope M.J. \& Springer M.S. 2002. Microbat 
paraphyly and the convergent evolution of a key innovation in Old World rhinolophoid microbats // Proceedings of the National Academy of Sciences of the USA. Vol.99. No.3. P.1431-1436.

Teeling E.C., Scally M., Kao D.J., Romagnoli M.L., Springer M.S. \& Stanhope M.J. 2000. Molecular evidence regarding the origin of echolocation and flight in bats // Nature. Vol.403. P.188-192.

Teeling E.C., Springer M.S., Madsen O., Bates P.J.J., O’Brien S.J. \& Murphey W.J. 2005. A molecular phylogeny for bats illuminates biogeography and the fossil record // Science. Vol.307. P.580-584.

Thabah A., Rossiter S.J., Kingston T., Zhang S., Parsons S., Mya K.M., Akbar Z. \& Jones G. 2006. Genetic divergence and echolocation call frequency in cryptic species of Hipposideros larvatus s.1. (Chiroptera: Hipposideridae) from the Indo-Malayan region // Biological Journal of the Linnean Society. Vol.88. No.1. P.119-130.

Tian L., Liang B., Maeda K., Metzner W. \& Zhang S. 2004. Molecular studies on the classification of Miniopterus schreibersii (Chiroptera: Vespertilionidae) inferred from mitochondrial cytochrome $b$ sequences // Folia Zoologica. Vol.53. P.303-311.

Tiunov M. P., Kruskop S.V. \& Jiang Feng. 2011. A new mouse-eared bat (Mammalia: Chiroptera, Vespertilionidae) from South China // Acta Chiropterologica. Vol.13. No.2. P.271-278.

Tu V.T., Cornette R., Utge J. \& Hassanin A. 2015. First records of Murina lorelieae (Chiroptera: Vespertilionidae) from Vietnam // Mammalia. Vol.79. No.2. P.201-213.

Tu V.T., Görföl T., Csorba G., Arai S., Kikuchi F., Fukui D., Koyabu D., Furey N., Bawm S., Linn K., Alviola P., Hang C., Son N.T., Tuan T. \& Hassanin A. 2021. Integrative taxonomy and biogeography of Asian yellow house bats (Vespertilionidae: Scotophilus) in the Indomalayan Region // Journal of Zoological Systematics and Evolutionary Research. Vol.59. No.3. P.772-795.

Uchida T.A. \& Ando K. 1972. Karyotype of the Eastern barbastelle, Barbastella leucomelas darjelingensis and comments on its phylogenetic position // Scientific Bulletin of Faculty of Agriculture, Kyushu University. No.1-4. P.393-398.

Vallo P., Guillen-Servent A., Benda P., Pires D.B. \& Koubek P. 2008. Variation of mitochondrial DNA in the Hipposideros caffer complex (Chiroptera: Hipposideridae) and its taxonomic implications // Acta Chiropterologica. Vol.10. No.2. P.193-206.

Van Den Bussche R.A. \& Hoofer S.R. 2001. Evaluating the monophyly of Nataloidea (Chiroptera) with mitochondrial DNA sequences // Journal of Mammalogy. Vol.82. No.2. P.320-327.

Van Den Bussche R.A. \& Hoofer S.R. 2004. Phylogenetic relationships among recent Chiropteran families and the importance of choosing appropriate out-group taxa // Journal of Mammalogy. Vol.85. No.2. P.321-330.

Van Den Bussche, R.A. \& Hoofer S.R. 2000. Further evidence for inclusion of the New Zealand short-tailed bat (Mystacina tuberculata) within Noctilionoidea // Journal of Mammalogy. Vol.73. No.1. P.29-42.

Volleth M. \& Heller K.G. 2012. Variations on a theme: karyotype comparison in Eurasian Myotis species and implications for phylogeny // Vespertilio. Vol.16. P.329-350.
Volleth M. 1985. Chromosomal homologies of the genera Vespertilio, Plecotus and Barbastella (Chiroptera: Vespertilionidae) // Genetica. Vol.66. P.231-236.

Volleth M. 1987. Differences in the location of nucleolus organizer regions in European vespertilionid bats // Cytogenetics and Cell Genetics. Vol.44. P.186-197.

Volleth M. 1992. Comparative analysis of the banded karyotypes of the European Nyctalus species (Vespertilionidae; Chiroptera) // Horacek I. \& Vohralik V. (eds.). Prague Studies in Mammalogy. Prague: Charles University Press. P.221-226.

Volleth M. \& Heller K.G. 1994. Phylogenetic relationships of vespertilionid genera (Mammalia: Chiroptera) as revealed by karyological analysis // Zeitschrift für Zoologische Systematik und Evolutionsforschung. Vol.32. P.11-34.

Volleth M., Biedermann M., Schorcht W. \& Heller K.-G. 2013. Evidence for two karyotypic variants of the lesser horseshoe bat (Rhinolophus hipposideros, Chiroptera, Mammalia) in central Europe // Cytogenetic and Genome Research. Vol.140. P.55-61.

Volleth M., Heller K.-G. \& Fahr J. 2006. Phylogenetic relationships of three "Nycticeiini" genera (Vespertilionidae, Chiroptera, Mammalia) as revealed by karyological analysis // Mammalian Biology. Vol.71. No.1. P.1-12.

Volleth M., Heller K.-G., Pfeiffer R.A. \& Hameister H. 2002. A comparative ZOO-FISH analysis in bats elucidates the phylogenetic relationships between Megachiroptera and five microchiropteran families // Chromosome Research. Vol.10. No.6. P.477-497.

Volleth M., Klett C., Kollak A., Dixkens C., Winter Y., Just W., Vogel W. \& Hameister H. 1999. ZOO-FISH analysis in a species of the order Chiroptera: Glossophaga soricina (Phyllostomidae) // Chromosome Research. Vol.7. P.57-64.

Volleth M., Loidl J., Mayer F., Yong H.-S., Mueller S. \& Heller K.G. 2015. Surprising genetic diversity in Rhinolophus luctus (Chiroptera: Rhinolophidae) from Peninsular Malaysia: description of a new species based on genetic and morphological characters // Acta Chiropterologica. Vol.17. No.1. P.1-20.

Volleth M., Müller S., Khan F.A.A., Yong H.-S., Heller K.G., Baker R.J., Ray D.A. \& Sotero-Caio C.G. 2019a. Cytogenetic investigations in Emballonuroidea. I. Taphozoinae and Emballonurinae karyotypes evolve at different rates and share no derived chromosomal characters // Acta Chiropterologica. Vol.21. No.2. P.257-269.

Volleth M., Müller S., Heller K.-G. \& Fahr J. 2019b. Cytogenetic Investigations in Emballonuroidea. II. Chromosome painting in Nycteridae reveals cytogenetic signatures pointing to common ancestry of Nycteris and Emballonura // Acta Chiropterologica. Vol.21. No.2. P.271-281.

Volleth M., Son N.T., Wu Y., Li Y., Yu W., Lin L.-K., Arai S., Trifonov V., Liehr T. \& Harada M. 2017. Comparative chromosomal studies in Rhinolophus formosae and $R$. luctus from China and Vietnam: Elevation of $R$. $l$. lanosus to species rank // Acta Chiropterologica. Vol.19. No.1. P.41-50.

Volleth M., Yang F. \& Müller S. 2011. High-resolution chromosome painting reveals the first genetic signature for the chiropteran suborder Pteropodiformes (Mammalia: 
Chiroptera) // Chromosome Research. Vol.19. No.14. P.507-519.

Warner J.W., Patton J.L., Gardner A.L. \& Baker R.J. 1974. Karyotypic analyses of twenty-one species of molossid bats (Molossidae: Chiroptera) // Canadian Journal of Genetics and Cytology. Vol.16. P.165-176.

Warnock R.C.M., Yang Z. \& Donoghue P.C.J. 2017. Testing the molecular clock using mechanistic models of fossil preservation and molecular evolution // Proceedings of the Royal Society, B. Biological Sciences. Vol.284. P.e20170227.

Wienberg J. 1995. Chromosome painting in mammals as an approach to comparative genomics // Current Opinion in Genetics \& Development. Vol.5. No.6. P.792-797.

Wiens J.J. 2009. Paleontology, genomics, and combined-data phylogenetics: can molecular data improve phylogeny estimation for fossil taxa? // Systematic Biology. Vol.58. P.87-99.

Wiens J.J., Kuczynski C.A., Townsend T., Reeder T.W., Mulcahy D.G., Sites J.W. 2010. Combining phylogenomics and fossils in higher-level squamate reptile phylogeny: molecular data change the placement of fossil taxa // Systematic Biology. Vol.59. P.674-688.

Wilson D.E. \& Reeder D.M. (eds.). 2005. Mammal Species of the World: a Taxonomic and Geographic Reference. Third edition. Vols.1-2. Baltimore: Johns Hopkins University Press. 2142 p.

Wilson D.E. \& Mittermeier R.A. (eds.). 2019. Handbook of the Mammals of the World. Vol.9, Bats. Barcelona: Lynx Edicions. 1008 p.
Wilson L.A.B., Hand S.J., López-Aguirre C., Archer M., Black K.H., Beck R.M.D., Armstrong K.M. \& Wroe S. 2016. Cranial shape variation and phylogenetic relationships of extinct and extant Old World leaf-nosed bats // Alcheringa. Vol.40. No.4. P.509-524.

Yusefovich A.P., Artyushin I.V., Raspopova A.A., Bannikova A.A. \& Kruskop S.V. 2020. An attempt to reconstruct the phylogeny of the Hipposideros leaf-nosed bats based on nuclear gene markers // Doklady Biological Sciences. Vol.493. P.136-140.

Zelditch M.L., Swiderski D.L. \& Sheets H.D. 2012. Geometric Morphometrics for Biologists: a Primer. Second edition. Amsterdam: Elsevier. 488 p.

Ziegler R. 2003. Bats (Chiroptera, Mammalia) from middle Miocene karstic fissure fillings of Petersbuch near Eichstätt, Southern Franconian Alb (Bavaria) // Géobios. Vol.36. P.447-490.

Zima J. 1976. Chromosomes of the two species of whiskered bat, Myotis mystacinus and Myotis brandti from Czechoslovakia (Vespertilionidae, Chiroptera) // Věstnik Československé Společnosti Zoologické. Vol.40. No.4. P.316-320.

Zima J., Volleth M., Horácek I., Cerveny J., Cervena A., Prucha K. \& Macholan M. 1992. Comparative karyology of rhinolophid bats (Chiroptera: Rhinolophidae) // Horácek I. \& Vohralik V. (eds.). Prague Studies in Mammalogy. Prague: Charles University Press. P.229-236. 